\title{
Differential Responses of Cucurbita pepo to Podosphaera xanthii Reveal the Mechanism of Powdery Mildew Disease Resistance in Pumpkin
}

\author{
Shuwu Zhang ${ }^{1,2}$, Jia Liu ${ }^{1}$, Bingliang $X u^{1,2 *}$ and Jingjiang Zhou ${ }^{1}$ \\ ${ }^{1}$ College of Plant Protection, Gansu Agricultural University, Biocontrol Engineering Laboratory of Crop Diseases and Pests of \\ Gansu Province, Lanzhou, China, ${ }^{2}$ Gansu Provincial Key Laboratory of Arid Land Crop Science, Gansu Agricultural \\ University, Lanzhou, China
}

OPEN ACCESS

Edited by:

Essaid Ait Barka

Université de Reims

Champagne-Ardenne, France

Reviewed by:

Mihir Kumar Mandal, Claflin University, United States

Wen-Ming Wang,

Sichuan Agricultural University, China

*Correspondence:

Bingliang Xu

xubl@gsau.edu.cn

Specialty section: This article was submitted to Plant Pathogen Interactions,

a section of the journal

Frontiers in Plant Science

Received: 24 November 2020 Accepted: 09 February 2021

Published: 12 April 2021

Citation:

Zhang S, LiU J, Xu B and Zhou J (2021) Differential Responses

of Cucurbita pepo to Podosphaera xanthii Reveal the Mechanism of Powdery Mildew Disease Resistance in Pumpkin.

Front. Plant Sci. 12:633221. doi: 10.3389/fp/s.2021.633221
Powdery mildew is one of the most destructive diseases and the major cause to the production losses of cucurbit worldwide. A number of strategies have been developed and applied to discover suitable and safer methods to manage the occurrence of powdery mildew disease in pumpkins (Cucurbita pepo L.), but information is limited in screening tolerant germplasms and exploring their mechanisms in preventing the disease occurrence at physiological, biochemical, and molecular levels. Therefore, we investigated the responses of two commercial pumpkin cultivars to Podosphaera xanthii infection. Compared with mock-inoculated seedlings, few small and sparse powdery areas were observed on the leaves of the Sixing $F_{1}$ cultivar on the $13^{\text {th }}$ day after inoculation with $P$. xanthii, whereas a large number of diseased powdery areas and a layer of white powdery mildew were observed on the surface of $\operatorname{Jin}_{12} F_{1}$ leaves. The inoculation duration $(7,9,11$, and 13 days) significantly and continuously increased the disease incidence and index of pumpkin seedlings. The contents of $\mathrm{H}_{2} \mathrm{O}_{2}, \mathrm{MDA}$, lignin, and total phenolics in the leaves of Sixing $F_{1}$ and $\operatorname{Jin}_{12} F_{1}$ cultivars were markedly increased after inoculation with $P$. xanthii. However, the Sixing $F_{1}$ cultivar exhibited much less reactive oxygen species (ROS) accumulation, a lower rate of lipid peroxidation, and a higher level of lignin and total phenolics contents after inoculation than the $\mathrm{Jin}_{12}$ $F_{1}$ cultivar. Compared with untreated control pumpkin seedlings, significantly higher activities and gene expressions of the phenylpropanoids pathway enzymes (PAL and PPO), ROS scavenging defense enzymes (SOD, CAT, POD, and APX), and other salicylic acid (SA) signaling pathway marker genes were observed in the leaves of both cultivars after $P$. xanthii inoculation at different inoculation time points. These enhancements were significantly higher in Sixing $F_{1}$ than $\operatorname{Jin}_{12} F_{1}$. Our results indicate that the Sixing $F_{1}$ cultivar exhibited a much stronger ability in resistance to $P$. xanthii infection than the $\operatorname{Jin}_{12} F_{1}$ cultivar. Our results suggest that one possible mechanism of $C$. pepo cultivars to prevent the pathogen $P$. xanthii infection is by activating and enhancing the activity and gene expression of the phenylpropanoids pathway to synthesize phenolic substances and lignin, ROS scavenging defense enzymes to eliminate the harmful effects of ROS, and signaling pathway marker gene expression to improve plant disease resistance.

Keywords: Cucurbita pepo, powdery mildew, Podosphaera xanthii, disease incidence and index, reactive oxygen species, phenylpropanoids and SA pathways, antioxidative defense system, gene expression 


\section{INTRODUCTION}

Powdery mildew is a common and widely distributed fungal disease that causes substantial yield and economic losses on a wide range of plants (Chen et al., 2020). Powdery mildew diseases are caused by many different species of fungi (Kusch and Panstruga, 2017; Babosha et al., 2020). Podosphaera xanthii has been considered as one of the most important pathogens that cause powdery mildew of cucurbit and reduce the cucurbit production worldwide (Tanaka et al., 2017). Pumpkin (Cucurbita pepo L.) is one of the most important vegetable crops for human nutrition worldwide (Hafez et al., 2018). Powdery mildew is one of the limiting factors that cause severely economic losses in pumpkin production by shortening the ripening and harvesting intervals, reducing photosynthesis and yields, and decreasing fruit quality in field and greenhouse (Cohen et al., 2000; Shi et al., 2007; Barickman et al., 2017). Normally, the pumpkin yield losses due to powdery mildew are 30-50\% (El-Naggar et al., 2012).

In the past few years, strategies have been adapted to manage powdery mildew in agriculture, including the use of chemical and biological fungicides, and breeding resistance varieties (El-Alfy and Schlenk, 2002; Faostat, 2010). However, the application of chemical fungicides is not healthy and safe due to their hazardous effects on beneficial organisms, plants, animals, and humans, as well as pathogen resistance (Abdel-Monaim et al., 2012). The resistance to powdery mildew was first observed in cucumber (Cucumis sativus L. cv. Puerto Rico 37) (Smith, 1948); thereafter, a large number of resistant materials were found in South and East Asia (Morishita et al., 2003). Although biological control agents have been applied to control powdery mildew, their efficacy is low and affected by environmental conditions (Dik et al., 1998). Thus, effective and environmentally friendly control strategies are needed to overcome these problems. Screening of resistant pumpkin germplasm would be the best way for developing new cultivars to prevent the powdery mildew occurrence. But little is known about the specific knowledge for discovering and developing new resistant pumpkin varieties to prevent powdery mildew occurrence. The mechanisms and nature of pumpkin resistance to $P$. xanthii infection remain unresolved.

A number of studies have demonstrated that plants can develop appropriate defense mechanisms to recognize and resist against fungal infection through the activation of their complex defense responses (Dangl and Jones, 2001). One of the earliest responses is the rapid generation of reactive oxygen species (ROS) such as hydrogen peroxide $\left(\mathrm{H}_{2} \mathrm{O}_{2}\right)$, hydroxyl radical $\left(\mathrm{OH}^{-}\right)$, and superoxide anion $\left(\mathrm{O}^{2-}\right)$ (Patykowski and Urbanek, 2003). ROS scavenging enzymes such as superoxide dismutase (SOD), peroxidase (POD), catalase (CAT), and ascorbate peroxidase (APX) play an essential role in regulating ROS levels and the extent of oxidative damage (Niu et al., 2018). The phenylpropanoid pathway is another defense response in higher plants (Irisarri et al., 2016; Hou et al., 2019). Phenylalanine ammonia-lyase (PAL) is the first enzyme that participates in the formation of a series of structurally different and defensive lignin and phenolic compounds (Vogt, 2010; Wang et al., 2013; Kamalipourazad et al., 2016; Han et al., 2017). Polyphenol oxidase (PPO) is another key enzyme in the synthesis of phenolic compounds for defending against pathogens in plants (Niu et al., 2018). In addition, previous studies revealed that SA plays an important role in fighting biotrophic pathogen infection and establishing systemic acquired resistance (SAR) (Dong, 1998; Edgar et al., 2006; Vlot et al., 2008; Fu et al., 2012). However, to our knowledge, there is little published information regarding the mechanisms of different cultivars of pumpkin C. pepo in resistance to $P$. xanthii infection through the phenylpropanoids and salicylic acid (SA) signaling pathways, and antioxidative defense systems.

Therefore, the aims of the present study were to (i) evaluate the ability and effectiveness of two commercial pumpkin cultivars in resistance to $P$. xanthii infection, (ii) determine the defense responses of the commercial pumpkin cultivars to the P. xanthii inoculation at different time points, and (iii) explore the possible mechanisms involved in two different pumpkin cultivars in response to $P$. xanthii infection at physiological, biochemical, and molecular levels.

\section{MATERIALS AND METHODS}

\section{Seeds Treatment}

The seeds of two commercial pumpkin cultivars (Sixing $F_{1}$ and $\operatorname{Jin}_{12} \mathrm{~F}_{1}$ ) were selected and kindly provided by Wuwei Golden Apple Co., Ltd. The seeds with a uniform size were surfacesterilized with $5 \% \mathrm{NaOCl}(\mathrm{v} / \mathrm{v})$ for $3 \mathrm{~min}$. Thereafter, all the surface-sterilized seeds were rinsed with sterile water five times and soaked in sterile water for $12 \mathrm{~h}$ for germination.

\section{Greenhouse Experiments}

The experiments were carried out in the greenhouse at Gansu Agricultural University in August 2013. The sterilized seeds were germinated in 9-cm Petri dishes and covered with two layers of absorbent cotton and blotter papers at a constant temperature of $25^{\circ} \mathrm{C}$. The germinated seeds were planted in pots $(12 \mathrm{~cm}$ in diameter) with $500 \mathrm{~g}$ of sterilized soil. Each pot was planted with 8 seeds and each cultivar had 12 pots (a total of 96 plants) after germination. The experiment was arranged in a completely randomized design in a greenhouse with the inside temperature maintained between 25 and $20^{\circ} \mathrm{C}$ (day and night), a photoperiod of $16 \mathrm{~L} / 8 \mathrm{D}$, and a relative humidity of $60 \%$. Irrigation was done twice weekly.

\section{Podosphaera xanthii Identification and Inoculum Preparation}

Pumpkin leaves infected with powdery mildew were collected from the field (Wuwei, China) on July 15, 2013 for microscopic observations. The pathogen was identified to be $P$. xanthii according to the published papers (McGrath and Thomas, 1996; Shin, 2000). The artificial inoculation of pumpkin seedlings was performed manually by dusting the sporulated leaves, and the plants with the P. xanthii isolate were kept for 20 days in a greenhouse. Five plants at the four-leaf stage with relatively consistent growth were selected, and three leaves of each plant were inoculated with the suspension of powdery mildew fungal 
pathogen $P$. xanthii spores by the smear method. The inoculated plants were placed in a greenhouse for the development of powdery mildew at 25 and $20^{\circ} \mathrm{C}$ (day and night), relative humidity of $60 \%$, and $16 \mathrm{~L} / 8 \mathrm{D}$ photoperiod. Control plants (mock-inoculated) were inoculated with the same volume of sterile water and maintained separately from the inoculated plants in the same greenhouse. The disease incidence, the disease index, the total lignin content, the total phenolic content, the hydrogen peroxide content, the lipid peroxidation content, the activity and gene expression level of phenylpropanoid pathway defense enzymes and ROS scavenging enzymes, and the expression level of SA signaling pathway marker genes at different time points were measured and calculated every 2 days after inoculation.

\section{Disease Incidence and Index Determination}

The disease incidence and index of both Sixing $F_{1}$ and $\operatorname{Jin}_{12} F_{1}$ cultivars were observed and recorded for both the inoculated and mock-inoculated plants every 2 days on $1,3,5,7,9,11$, and 13 days post inoculation (dpi). Five plants from each treatment and control were used as one independent replicate per time point. Twelve such replicates were set up per treatment. Disease severity was recorded on the individual pot of each cultivar. Based on the powdery mildew symptoms developed on the host plants, a scale of 1-9 of increasing disease severity was used according to the standard described by Liu et al. (2006).

Scale levels:

\section{0: no symptoms;}

1: the infected areas less than $30 \%$ in the front of the leaves and no symptoms in the reverse of the leaves;

3: the infected areas greater than $30 \%$ in the front of the leaves and less than $10 \%$ in the reverse of the leaves;

5: the infected areas greater than 30 and $10 \%$ in the front and reverse of the leaves, respectively, and a few lesions appeared on the petioles;

7: the powdery mildew covered in the front of the leaves and the infected areas greater than $10 \%$ in the reverse of the leaves, and more lesions appeared on the petioles and a few on the main stems;

9: the powdery mildew covered in the front of the leaves, petioles, and main stems, and the infected areas greater than $10 \%$ in the reverse of the leaves.

The calculation formulas for the disease incidence and index are as follows:

$$
\text { Disease incidence }(\%)=(\text { NIL/TNIL }) \times 100
$$

where NIL is the number of infected leaves, and TNIL is the total number of investigated leaves.

Disease index $=(\Sigma$ NDL $\times$ GLDS $) /($ TNIL $\times$ THGL $) \times 100$

where NDL is the number of diseased leaves in each level; GLDS is the grade level of disease severity; TNIL is the total number of investigated leaves; and THGL is the highest-grade level.

\section{Leaf Cell Wall Isolation and Lignin Content Determination}

The leaf cell walls were isolated according to the method described by Eskandari et al. (2018). Briefly, fresh leaf sample $(0.5 \mathrm{~g})$ was frozen and ground to powder in liquid nitrogen. The sample powder was homogenized in distilled water and then centrifuged at $10,000 \mathrm{~g}$ for $10 \mathrm{~min}$. The precipitation was washed with absolute ethanol, rinsed with the mixture solution of chloroform and methanol $(\mathrm{v} / \mathrm{v}=1: 2)$, and then washed with acetone three times. The cell wall pellet was filtered and finally dried overnight at $35^{\circ} \mathrm{C}$. The residue (cell wall) was collected and kept at room temperature until use.

The content of lignin was determined and assayed by following the procedure of Iiyama and Wallis (1990). The cell wall preparation $\left(5 \mathrm{mg}\right.$ ) was treated at $70^{\circ} \mathrm{C}$ for $30 \mathrm{~min}$ with the mixture solution $(2.5 \mathrm{ml})$ of $5 \%$ acetyl bromide and AcHO (w/w) and $0.1 \mathrm{ml}$ of $70 \% \mathrm{HClO}$. After cooling, the reaction mixture was treated with $50 \mathrm{ml}$ of $2 \mathrm{M} \mathrm{NaOH}$ and AcHO. The lignin content was determined by measuring the absorbance at $280 \mathrm{~nm}$ and calculated using a specific absorption coefficient of $20.0 \mathrm{~g}^{-1} 1 \mathrm{~cm}^{-1}$.

\section{Total Phenolics Content Determination}

The content of total phenolics was measured according to the method described by Singleton and Rossi (1965) with a minor modification. The fresh leaf sample $(0.5 \mathrm{~g})$ was ground with quartz sand and then extracted with $70 \%$ ethanol $(10 \mathrm{ml})$ for $10 \mathrm{~min}$. The mixture was centrifuged at $12,000 \mathrm{~g}$ for $20 \mathrm{~min}$. The absorbance of the supernatant at $760 \mathrm{~nm}$ was used to determine the total phenolic content and expressed as $\mathrm{mg} \mathrm{g}^{-1} \mathrm{FW}$.

\section{Phenylpropanoid Pathway Enzyme Activity Determination}

The fresh leaf sample $(0.5 \mathrm{~g})$ was homogenized in a $6 \mathrm{ml}$ icecold borate buffer $(5 \mathrm{mM}, \mathrm{pH} 8.8)$ using a pre-chilled mortar and pestle, and then centrifuged at $8,000 \mathrm{~g}$ for $20 \mathrm{~min}$ at $4^{\circ} \mathrm{C}$. The supernatant was mixed with $0.02 \mathrm{M}$ phenylalanine and distilled water and used as crude extracts. The extract was incubated at $30^{\circ} \mathrm{C}$ for $30 \mathrm{~min}$ and then measured at $290 \mathrm{~nm}$ for the determination of PAL activity (Ruiz et al., 1999; Hu et al., 2009), and at $420 \mathrm{~nm}$ for the determination of PPO activity following the oxidation of catechol (Chang et al., 2000). The activity of PAL and PPO was expressed as $\mathrm{U} \min ^{-1} \mathrm{~g}^{-1} \mathrm{FW}$.

\section{Hydrogen Peroxide $\left(\mathrm{H}_{2} \mathrm{O}_{2}\right)$ and Lipid Peroxidation (MDA) Content Determination}

For the determination of the $\mathrm{H}_{2} \mathrm{O}_{2}$ content in the leaves of different pumpkin cultivars, the fresh leaf sample $(0.5 \mathrm{~g})$ was homogenized in $5 \mathrm{ml}$ of precooled $\mathrm{HClO}_{4}(1.0 \mathrm{M})$ using the prechilled mortar and pestle and then centrifuged at 10,000 $\mathrm{g}$ for 10 min. The content of $\mathrm{H}_{2} \mathrm{O}_{2}$ was determined and calculated according to the method described by Willekens et al. (1997) and expressed as $\mu \mathrm{mol} \mathrm{g}^{-1} \mathrm{FW}$.

The level of lipid peroxidation was determined by quantifying the MDA accumulation in the leaves of different pumpkin 
cultivars according to the method described by Hodges et al. (1999) and Tian et al. (2015) with some modifications. Briefly, the fresh leaf sample $(0.5 \mathrm{~g})$ was homogenized in $2.5 \mathrm{ml}$ of $0.1 \%$ trichloroacetic acid and then centrifuged at 10,000 g for $15 \mathrm{~min}$. The absorbance of the supernatant was recorded at a $532-\mathrm{nm}$ wavelength. The content of MDA was expressed as nmol g ${ }^{-1} \mathrm{FW}$.

\section{ROS Scavenging Enzyme Activity Determination}

The fresh leaf sample (1 g) was homogenized in an ice-cold buffer ( $\mathrm{pH} 7.8$ ) with $10 \mathrm{ml}$ of $25 \mathrm{mM}$ potassium phosphate containing $0.2 \mathrm{mM}$ EDTA and $2 \%$ polyvinylpyrrolidone. The homogenate was centrifuged at $10,000 \mathrm{~g}$ for $25 \mathrm{~min}$ at $4^{\circ} \mathrm{C}$, and then the supernatant was used as an enzyme extract to determine the activity of ROS scavenging enzymes (SOD, POD, CAT, and APX). All spectrophotometric analyses were conducted on a spectrophotometer (SP-756P, Shanghai, China). The activity of ROS scavenging enzymes was expressed as $\mathrm{U} \mathrm{g}^{-1} \mathrm{~min}^{-1} \mathrm{FW}$.

The SOD activity was measured according to the method of Giannopolitis and Ries (1977) with a minor modification. The POD activity was determined and assayed according to the method described by Chance and Maehly (1955) and Cakmak and Marschner (1992) with a minor modification. The CAT activity was measured according to Patra et al. (1978) by measuring the decrease in the amount of the $\mathrm{H}_{2} \mathrm{O}_{2}$ decomposing at the absorbance of $240 \mathrm{~nm}$. The APX activity was measured according to Nakano and Asada (1981) by estimating the rate of ascorbate oxidation at $290 \mathrm{~nm}$.

\section{Total RNA Extraction and First-Strand cDNA Synthesis}

The leaf samples were collected every 2 days post inoculation (dpi) for both inoculated and mock-inoculated seedlings on
1, 3, 5, 7, 9, 11, and 13 days dpi from both Sixing $F_{1}$ and $\operatorname{Jin}_{12} F_{1}$ cultivars for total RNA extractions. Five plants from each treatment were used as one independent replicate per time point. Total RNA extraction and first-strand cDNA synthesis were carried out according to the methods described by Zhang et al. (2016).

\section{Real-Time Quantitative PCR (RT-qPCR) Analysis}

The gene expression level of phenylpropanoid pathway defense enzymes (PAL and PPO) (Bezold et al., 2005; Zhu et al., 2018), ROS scavenging enzymes ( $S O D, P O D, C A T, A P X)$ (Yao et al., 2018; Liu et al., 2020), and SA signaling pathway marker genes (PR1, PR2 and ICS1) (Wang et al., 2010; Yan, 2018; Luan et al., 2019) was determined in pumpkin leaves inoculated with $P$. xanthii and mock-inoculated pumpkin leaves at different time points after inoculation. The procedure of RT-qPCR was performed following the methods of Zhang et al. (2016). The sequences of the primers used in the RT-qPCR analyses were designed using the Primer Express 3.0 software based on the sequences of target genes in NCBI and listed in Table 1. The actin gene of pumpkin was used as an internal control (Bezold et al., 2005). The gene expression level was determined using the method of $2^{-\Delta \Delta \mathrm{Ct}}$ (Livak and Schmittgen, 2001).

\section{Statistical Analysis}

The data were subjected to variance analysis (ANOVA) using SPSS Version 16.0 (SPSS Inc., Chicago, IL). Each treatment had 12 replications. Duncan's multiple range test was computed using the standard error and $\mathrm{T}$ values of adjusted degrees of freedom. The differences between treatments were considered significant at the level of $P<0.05$.

TABLE 1 | Gene-specific PCR primers for target genes and Actin gene.

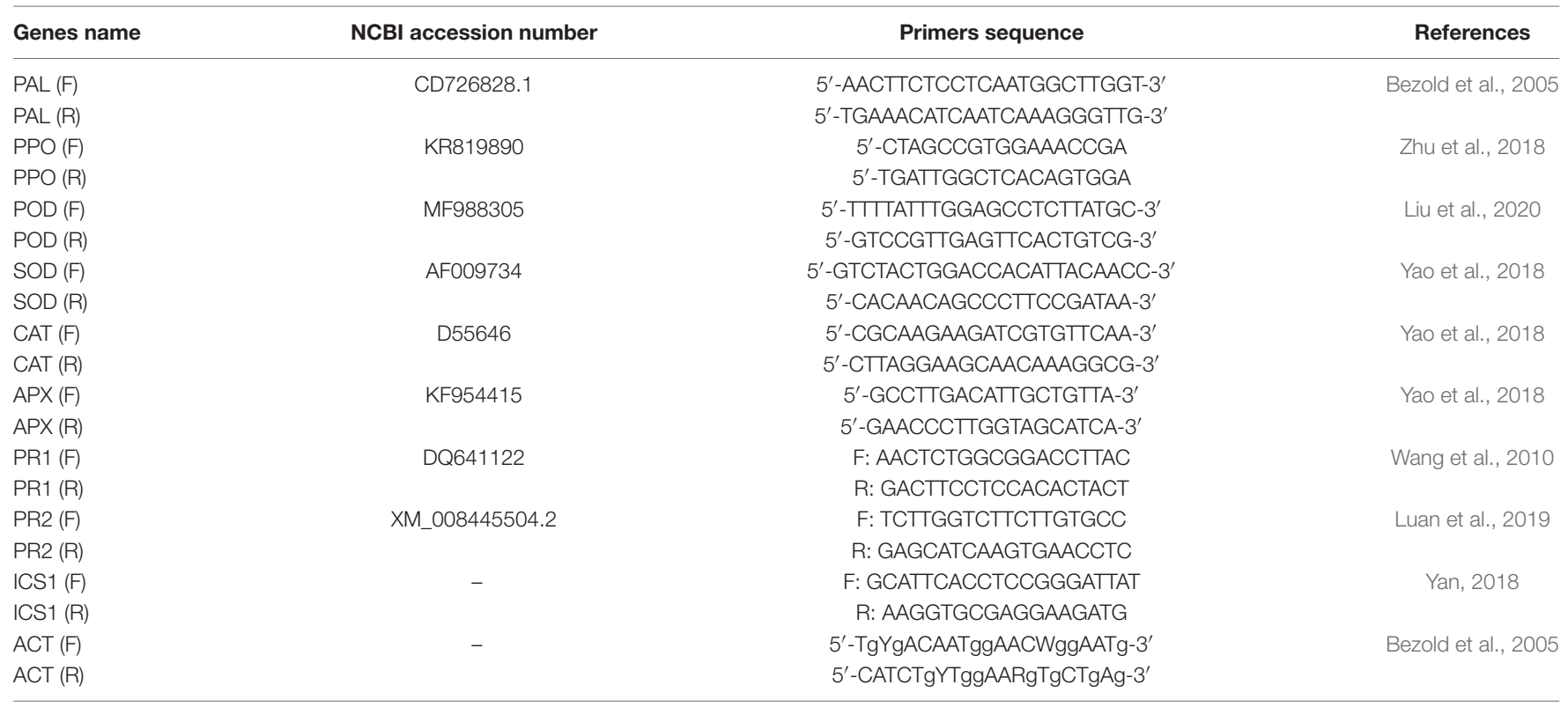

Frepresents forward; $R$ represents reverse. 

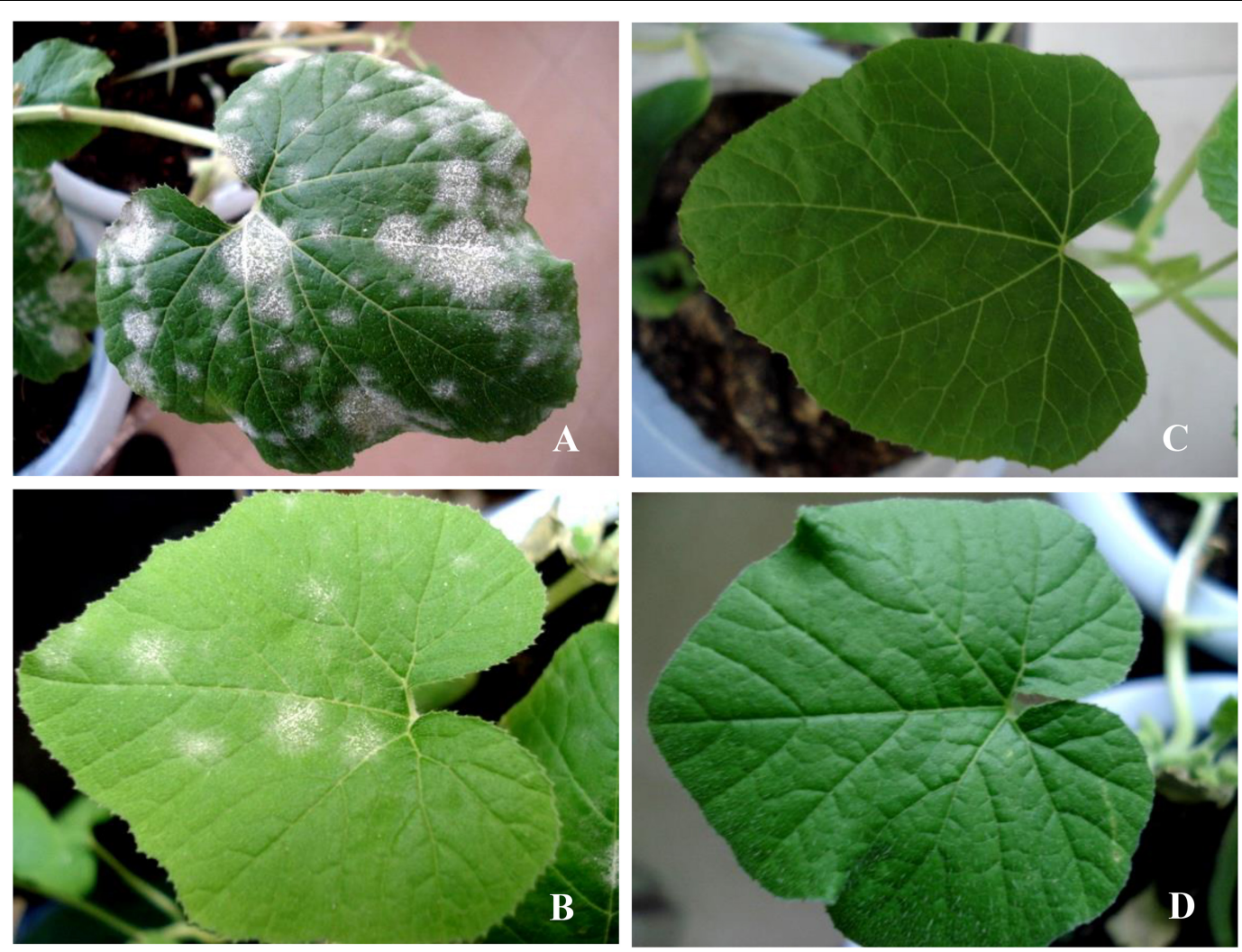

FIGURE 1 | The symptoms of different cultivars of Cucurbita pepo on the $13^{\text {th }}$ day after inoculation with the pathogen of Podosphaera xanthii. (A) The cultivar of $\operatorname{Jin}_{12} F_{1}$ after inoculation with P. xanthii; (B) the cultivar of Sixing $F_{1}$ after inoculation with $P$. xanthii; (C) the cultivar of Jin $12 F_{1}$ after inoculation with sterile water but not $P$. xanthii; and (D) the cultivar of Sixing $F_{1}$ after inoculation with sterile water but not $P$. xanthii.

\section{RESULTS}

\section{Symptoms of C. pepo After Inoculation With $P$. xanthii}

A large number of diseased powdery areas and a layer of white powdery mildew were observed on the surface of Jin ${ }_{12} \mathrm{~F}_{1}$ leaves (Figure 1A) on the $13^{\text {th }}$ day after inoculation with $P$. xanthii in comparison to the leaves of the mock-inoculated $\operatorname{Jin}_{12} \mathrm{~F}_{1}$ seedlings (Figure 1C). However, small and sparse powdery areas were observed on the leaves of the Sixing $F_{1}$ cultivar (Figure 1B), and no diseased powdery area was observed on the leaves of the mock-inoculated Sixing $F_{1}$ (Figure 1D).

\section{Disease Severity of C. pepo After Inoculation With $P$. xanthii}

The cultivars of $\operatorname{Jin}_{12} F_{1}$ and Sixing $F_{1}$ inoculated with $P$. xanthii begun to show the disease symptoms at the fifth and seventh day after the inoculation. The disease incidence and index were significantly different between the cultivars of Sixing $F_{1}$ and $\operatorname{Jin}_{12}$ $\mathrm{F}_{1}$ (Tables 2, 3) $(P<0.05)$ after inoculation with $P$. xanthii. In contrast, the mock-inoculated seedlings grew normally and had no disease symptoms during the inoculation.

The disease incidence and index of two pumpkin cultivars were significantly and continuously increased by the increase in the inoculation time $(7,9,11$, and 13 days). The disease incidence and index of $\operatorname{Jin}_{12} \mathrm{~F}_{1}$ cultivar were significantly higher than those of the Sixing $F_{1}$ cultivar. At day 13, the disease incidence and index of the $\operatorname{Jin}_{12} \mathrm{~F}_{1}$ cultivar were $80.0 \%$ and 72.6, respectively, whereas they were only $22.3 \%$ and 17.7 in the Sixing $\mathrm{F}_{1}$ cultivar, respectively. In addition, the $\operatorname{Jin}_{12} \mathrm{~F}_{1}$ cultivar begun to show symptoms at the fifth day after inoculation, while the Sixing $F_{1}$ cultivar begun to show symptoms at the seventh day after inoculation. Furthermore, the expansion speed of the diseased powdery area in the $\operatorname{Jin}_{12} \mathrm{~F}_{1}$ cultivar was faster than in the Sixing $F_{1}$ cultivar with the increase in the inoculation time (Tables 2, 3).

\section{Lignin and Total Phenolics Contents in Pumpkin Seedlings}

The lignin and total phenolics contents in the leaves of the cultivars of Sixing $F_{1}$ and $\operatorname{Jin}_{12} F_{1}$ were increased from 1 to 9 or 11 days by the treatment with $P$. xanthii and peaked on the $9^{\text {th }}$ and $11^{\text {th }}$ days. The levels of lignin and total phenolics of the Sixing $\mathrm{F}_{1}$ cultivar were significantly higher in comparison to those of the $\operatorname{Jin}_{12} \mathrm{~F}_{1}$ cultivar. The average contents of lignin and total phenolics on the $9^{\text {th }}$ to $11^{\text {th }}$ days were significantly increased by the inoculation to 21.24 and $21.09 \%$ in the leaves of the Sixing 
TABLE 2 | The disease incidence of different cultivars of Cucurbita pepo after inoculation with Podosphaera xanthii.

\begin{tabular}{|c|c|c|c|c|c|c|c|c|}
\hline \multirow{2}{*}{ Cultivars } & \multirow{2}{*}{ Treatments } & \multicolumn{7}{|c|}{ Days post inoculation (dpi) } \\
\hline & & 1 & 3 & 5 & 7 & 9 & 11 & 13 \\
\hline & & \multicolumn{7}{|c|}{ Disease incidence (\%) } \\
\hline \multirow{2}{*}{ Sixing F1 } & Treatment & $0.0 \mathrm{a}$ & $0.0 \mathrm{a}$ & $0.0 \mathrm{~b}$ & $6.7 \mathrm{~b}$ & $16.7 \mathrm{~b}$ & $21.3 b$ & $22.3 b$ \\
\hline & Control & $0.0 \mathrm{a}$ & $0.0 \mathrm{a}$ & $0.0 \mathrm{~b}$ & $0.0 \mathrm{c}$ & $0.0 \mathrm{c}$ & $0.0 \mathrm{c}$ & $0.0 \mathrm{c}$ \\
\hline \multirow{2}{*}{ Jin12 F1 } & Treatment & $0.0 \mathrm{a}$ & $0.0 \mathrm{a}$ & $3.3 \mathrm{a}$ & $26.7 \mathrm{a}$ & $60.0 \mathrm{a}$ & $76.7 \mathrm{a}$ & $80.0 \mathrm{a}$ \\
\hline & Control & $0.0 \mathrm{a}$ & $0.0 \mathrm{a}$ & $0.0 \mathrm{~b}$ & $0.0 \mathrm{c}$ & $0.0 \mathrm{c}$ & $0.0 \mathrm{c}$ & $0.0 \mathrm{c}$ \\
\hline \multicolumn{9}{|c|}{$\begin{array}{l}\text { Data are means of } 12 \text { replicates. Different letters in the same column denote significant differences at the } P<0.05 \text { level by Duncan's new multiple range test ( } n=12 \text { ). In } \\
\text { the two treatments, pumpkin seedling leaves were inoculated with P. xanthii, whereas in the two controls, pumpkin seedling leaves were inoculated with sterile water but } \\
\text { not P. xanthii. }\end{array}$} \\
\hline \multirow{3}{*}{ Cultivars } & & \multicolumn{7}{|c|}{ Days post inoculation (dpi) } \\
\hline & 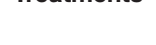 & 1 & 3 & 5 & 7 & 9 & 11 & 13 \\
\hline & & \multicolumn{7}{|c|}{ Disease index } \\
\hline \multirow{2}{*}{ Sixing $F_{1}$} & Treatment & $0.0 \mathrm{a}$ & $0.0 \mathrm{a}$ & $0.0 \mathrm{~b}$ & $4.7 \mathrm{~b}$ & $13.3 b$ & $16.4 \mathrm{~b}$ & $17.7 b$ \\
\hline & Control & $0.0 \mathrm{a}$ & $0.0 \mathrm{a}$ & $0.0 \mathrm{~b}$ & $0.0 \mathrm{c}$ & $0.0 \mathrm{c}$ & $0.0 \mathrm{c}$ & $0.0 \mathrm{c}$ \\
\hline \multirow{2}{*}{$\operatorname{Jin}_{12} F_{1}$} & Treatment & $0.0 \mathrm{a}$ & $0.0 \mathrm{a}$ & $3.3 \mathrm{a}$ & $16.7 \mathrm{a}$ & $40.7 \mathrm{a}$ & $46.0 \mathrm{a}$ & $72.6 \mathrm{a}$ \\
\hline & Control & $0.0 \mathrm{a}$ & $0.0 \mathrm{a}$ & $0.0 \mathrm{~b}$ & $0.0 \mathrm{c}$ & $0.0 \mathrm{c}$ & $0.0 \mathrm{c}$ & $0.0 \mathrm{c}$ \\
\hline
\end{tabular}

Data are means of 12 replicates. The different letters and treatments are detailed in the footnote of Table 2

TABLE 4 | Lignin and total phenolic content in different cultivars of Cucurbita pepo seedlings after inoculation with Podosphaera xanthii.

\begin{tabular}{|c|c|c|c|c|c|c|c|c|}
\hline \multirow{2}{*}{ Cultivars } & \multirow{2}{*}{ Treatments } & \multicolumn{7}{|c|}{ Days post inoculation (dpi) } \\
\hline & & 1 & 3 & 5 & 7 & 9 & 11 & 13 \\
\hline & & \multicolumn{7}{|c|}{ Lignin content ( $\%$ of cell wall dry weight) } \\
\hline \multirow{2}{*}{ Sixing $F_{1}$} & Treatment & $2.56 \mathrm{a}$ & $2.89 \mathrm{a}$ & $3.28 \mathrm{a}$ & $5.08 \mathrm{a}$ & $6.56 \mathrm{a}$ & $6.52 \mathrm{a}$ & $6.13 \mathrm{a}$ \\
\hline & Control & $2.43 \mathrm{~b}$ & $2.78 b$ & $3.09 \mathrm{~b}$ & $4.25 \mathrm{~b}$ & $5.34 \mathrm{~b}$ & $5.45 b$ & $5.25 \mathrm{~b}$ \\
\hline \multirow{3}{*}{$\operatorname{Jin}_{12} F_{1}$} & Treatment & $2.12 \mathrm{c}$ & $2.24 \mathrm{c}$ & $2.67 \mathrm{c}$ & $3.11 \mathrm{c}$ & $3.98 \mathrm{c}$ & $4.02 \mathrm{c}$ & $3.96 \mathrm{c}$ \\
\hline & Control & $2.01 \mathrm{c}$ & $2.15 \mathrm{c}$ & $2.48 \mathrm{~d}$ & $2.81 \mathrm{~d}$ & $3.51 \mathrm{~d}$ & $3.61 \mathrm{~d}$ & $3.74 \mathrm{~d}$ \\
\hline & & \multicolumn{7}{|c|}{ Total phenolics content (mg g $\left.{ }^{-1} \mathrm{FW}\right)$} \\
\hline \multirow{2}{*}{ Sixing $F_{1}$} & Treatment & $3.62 \mathrm{a}$ & $3.85 \mathrm{a}$ & $3.98 \mathrm{a}$ & $4.29 \mathrm{a}$ & $4.79 \mathrm{a}$ & $4.81 \mathrm{a}$ & $4.25 \mathrm{a}$ \\
\hline & Control & $3.35 b$ & $3.42 b$ & $3.62 \mathrm{~b}$ & $3.98 \mathrm{~b}$ & $4.02 \mathrm{~b}$ & $3.91 \mathrm{c}$ & $4.06 \mathrm{~b}$ \\
\hline \multirow{2}{*}{$\operatorname{Jin}_{12} F_{1}$} & Treatment & $3.34 \mathrm{~b}$ & $3.57 b$ & $3.72 b$ & $3.89 \mathrm{~b}$ & $4.21 \mathrm{~b}$ & $4.33 b$ & $3.98 \mathrm{bc}$ \\
\hline & Control & $3.01 \mathrm{c}$ & $3.12 \mathrm{c}$ & $3.23 \mathrm{c}$ & $3.45 \mathrm{c}$ & $3.64 \mathrm{c}$ & $3.56 \mathrm{~d}$ & $3.54 \mathrm{c}$ \\
\hline
\end{tabular}

Data are means of 12 replicates. The different letters and treatments are detailed in the footnote of Table 2.

$\mathrm{F}_{1}$ cultivar and to 12.38 and $18.65 \%$ in the leaves of the $\operatorname{Jin}_{12} \mathrm{~F}_{1}$ cultivar in comparison to the control, respectively (Table 4).

\section{Activity of the Phenylpropanoids Pathway Defense Enzymes}

The activities of the phenylpropanoids pathway enzymes PAL and PPO in different pumpkin cultivars (Sixing $\mathrm{F}_{1}$ and $\operatorname{Jin}_{12} \mathrm{~F}_{1}$ ) were increased significantly on the 5 th day after the $P$. xanthii inoculation, peaked on the $9^{\text {th }}$ or $11^{\text {th }}$ day, and then declined gradually (Figure 2). However, the activity of PAL and PPO differed significantly between the Sixing $\mathrm{F}_{1}$ cultivar and the $\operatorname{Jin}_{12}$ $\mathrm{F}_{1}$ cultivar. A higher level of PAL and PPO activity was detected in Sixing $F_{1}$ leaves than in $\operatorname{Jin}_{12} F_{1}$ leaves. Compared with those of the untreated control, the PAL and PPO activities in the leaves of the Sixing $\mathrm{F}_{1}$ cultivar were increased by $32.52 \%$ (Figure $2 \mathrm{~A}$ ) and $42.42 \%$ (Figure $2 \mathrm{C}$ ) on the $9^{\text {th }}$ day, respectively. In contrast, the PAL and PPO activities in the leaves of the $\operatorname{Jin}_{12} \mathrm{~F}_{1}$ cultivar were increased by $12.84 \%$ (Figure 2B) and $15.43 \%$ (Figure 2D) on the $9^{\text {th }}$ day, respectively.

\section{Hydrogen Peroxide $\left(\mathrm{H}_{2} \mathrm{O}_{2}\right)$ and Lipid Peroxidation (MDA) Contents in Pumpkin Seedling}

The $\mathrm{H}_{2} \mathrm{O}_{2}$ and MDA contents of Sixing $\mathrm{F}_{1}$ and $\mathrm{Jin}_{12} \mathrm{~F}_{1}$ seedling leaves were increased with the duration of post inoculation with $P$. xanthii, peaked on the $9^{\text {th }}$ and $11^{\text {th }}$ days, and then declined 

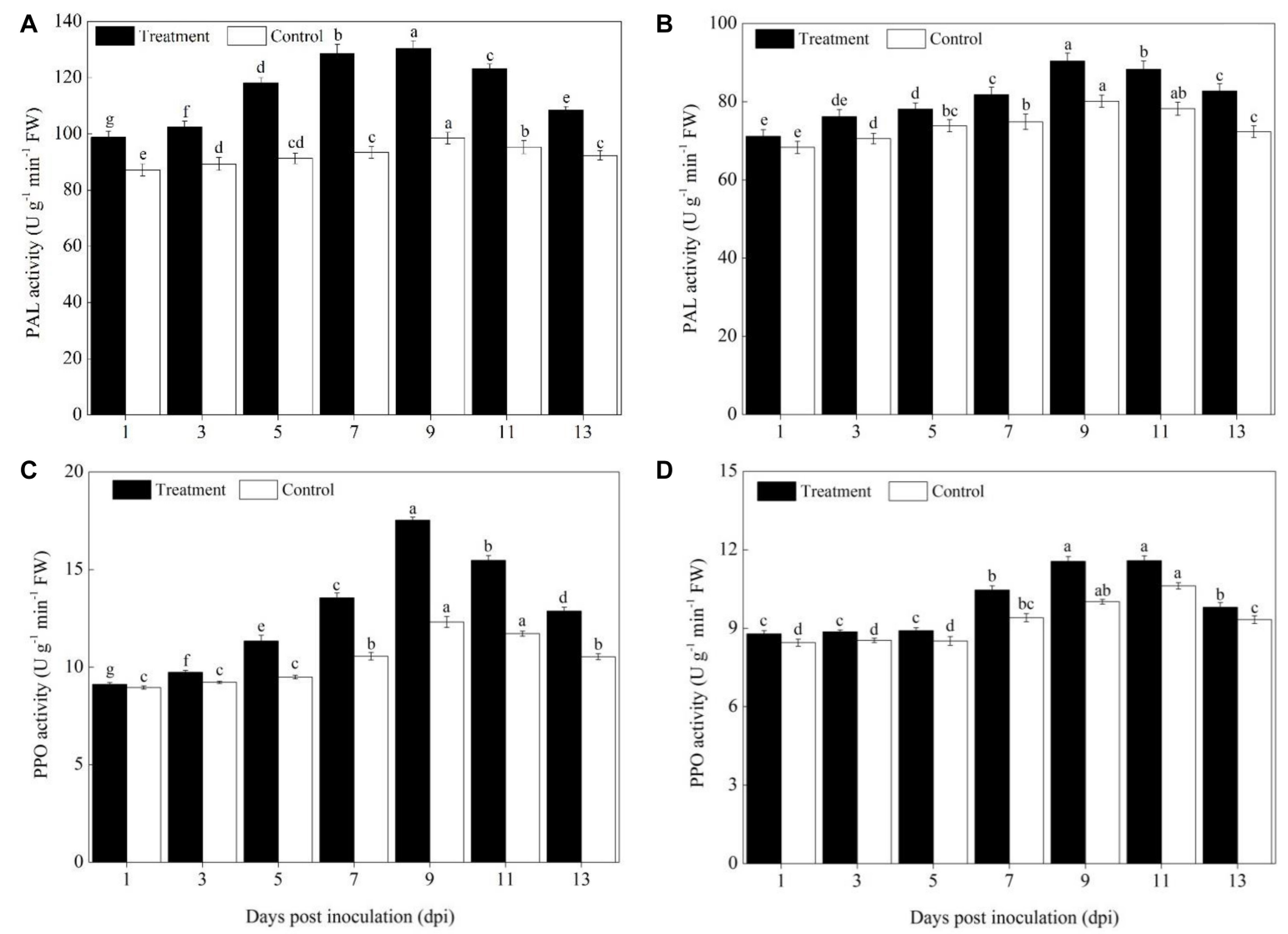

FIGURE 2 | PAL and PPO activity in the leaves of Sixing $F_{1}$ and $\operatorname{Jin}_{12} F_{1}$ at different time points after inoculation with Podosphaera xanthii. (A) The PAL activity in the leaves of Sixing $\mathrm{F}_{1}$; (B) the PAL activity in the leaves of $\mathrm{Jin}_{12} \mathrm{~F}_{1} ; \mathbf{( C )}$ the PPO activity in the leaves of Sixing $\mathrm{F}_{1}$; and (D) the PPO activity in the leaves of Jin 12 F $\mathrm{F}_{1}$. The line bars represent the standard errors of the means. Different letters denote significant difference at the $P<0.05$ level by Duncan's new multiple range test $(n=12)$. The treatments are detailed in the footnote of Table 2.

gradually. The $\mathrm{H}_{2} \mathrm{O}_{2}$ and MDA contents in the Jin $12 \mathrm{~F}_{1}$ leaves were significantly higher than those in the Sixing $\mathrm{F}_{1}$ leaves. The maximum $\mathrm{H}_{2} \mathrm{O}_{2}$ and MDA contents were increased significantly by 26.83 and $26.42 \%$ in the Sixing $F_{1}$ leaves and 27.08 and $28.32 \%$ in the $\operatorname{Jin}_{12} \mathrm{~F}_{1}$ leaves on the $9^{\text {th }}$ and $11^{\text {th }}$ days after inoculation with $P$. xanthii, respectively, compared with those of control leaves inoculated with sterile water (Table 5).

\section{Activity of ROS Scavenging Defense Enzymes}

The activity of ROS scavenging enzymes (SOD, POD, CAT, and APX) was significantly increased in the cultivars of Sixing $F_{1}$ and $\operatorname{Jin}_{12} \mathrm{~F}_{1}$ after being inoculated with the pathogen of $P$. xanthii from the $3^{\text {rd }}$ to $11^{\text {th }}$ day in comparison to the control (Figure 3 ). In addition, a higher activity of ROS scavenging enzymes was observed in the leaves of the Sixing $\mathrm{F}_{1}$ cultivar in comparison to the $\operatorname{Jin}_{12} \mathrm{~F}_{1}$ cultivar.

The SOD induction reached its maximum from the $7^{\text {th }}$ to $9^{\text {th }}$ day in the leaves of Sixing $F_{1}$ and $\operatorname{Jin}_{12} F_{1}$ after inoculation and then declined. Compared with the control seedlings inoculated with sterile water, the average SOD activity was increased by $28.47 \%$ in the Sixing $F_{1}$ leaves (Figure 3A) and $11.48 \%$ in the $\operatorname{Jin}_{12}$
$F_{1}$ leaves (Figure $3 B$ ) on the $7^{\text {th }}$ and $9^{\text {th }}$ days after inoculation with $P$. xanthii. In addition, the activity of SOD in the leaves of the Sixing $F_{1}$ cultivar was significantly higher than in the leaves of the $\operatorname{Jin}_{12} \mathrm{~F}_{1}$ cultivar. The average SOD activity in the Sixing $\mathrm{F}_{1}$ leaves was $30.33 \mathrm{U} \mathrm{g}^{-1} \mathrm{~min}^{-1} \mathrm{FW}$, whereas it was $22.15 \mathrm{U} \mathrm{g}^{-1} \mathrm{~min}^{-1}$ $\mathrm{FW}$ in the $\operatorname{Jin}_{12} \mathrm{~F}_{1}$ leaves on the $7^{\text {th }}$ and $9^{\text {th }}$ days after inoculation.

The CAT activity in the Sixing $\mathrm{F}_{1}$ leaves was significantly increased up to the $7^{\text {th }}$ and $9^{\text {th }}$ days, whereas in the $\operatorname{Jin}_{12} F_{1}$ leaves, it was significantly increased up to the $9^{\text {th }}$ and $11^{\text {th }}$ days after inoculation, and then declined in all the treatments. However, the CAT activity of the Sixing $F_{1}$ cultivar was significantly higher than that of the $\operatorname{Jin}_{12} F_{1}$ cultivar. The CAT activity on the $9^{\text {th }}$ day after inoculation was $25.61 \mathrm{U} \mathrm{g}^{-1} \mathrm{~min}^{-1} \mathrm{FW}$ in the Sixing $\mathrm{F}_{1}$ leaves, whereas it was $19.45 \mathrm{U} \mathrm{g}^{-1} \mathrm{~min}^{-1} \mathrm{FW}$ in the $\operatorname{Jin}_{12} \mathrm{~F}_{1}$ leaves. The CAT activity on the $9^{\text {th }}$ day after being inoculated with $P$. xanthii was increased by $20.65 \%$ in Sixing $F_{1}$ leaves (Figure 3C), whereas it was increased by $1.57 \%$ in the $\operatorname{Jin}_{12} \mathrm{~F}_{1}$ leaves (Figure 3D) in comparison to those in the control leaves inoculated with sterile water but not P. xanthii.

The inoculation of $P$. xanthii induced the maximum (peak) level of POD activity in the cultivars of Sixing $F_{1}$ and $\operatorname{Jin}_{12} F_{1}$ on the $9^{\text {th }}$ and $11^{\text {th }}$ days, respectively, and thereafter it declined. 
TABLE 5 | $\mathrm{H}_{2} \mathrm{O}_{2}$ and MDA content in different cultivars of Cucurbita pepo seedlings after inoculation with Podosphaera xanthii.

\begin{tabular}{|c|c|c|c|c|c|c|c|c|}
\hline \multirow{2}{*}{ Cultivars } & \multirow{2}{*}{ Treatments } & \multicolumn{7}{|c|}{ Days post inoculation (dpi) } \\
\hline & & 1 & 3 & 5 & 7 & 9 & 11 & 13 \\
\hline & & \multicolumn{7}{|c|}{$\mathrm{H}_{2} \mathrm{O}_{2}\left(\mu \mathrm{mol} \mathrm{g}^{-1} \mathrm{FW}\right)$} \\
\hline \multirow{2}{*}{ Sixing $F_{1}$} & Treatment & $0.25 \mathrm{c}$ & $0.28 \mathrm{~b}$ & $0.39 \mathrm{a}$ & $0.46 \mathrm{~b}$ & $0.52 \mathrm{~b}$ & $0.47 \mathrm{~b}$ & $0.38 c$ \\
\hline & Control & $0.23 d$ & $0.25 \mathrm{c}$ & $0.32 \mathrm{c}$ & $0.37 \mathrm{~d}$ & $0.41 \mathrm{~d}$ & $0.43 \mathrm{c}$ & $0.35 d$ \\
\hline \multirow{2}{*}{$\operatorname{Jin}_{12} F_{1}$} & Treatment & $0.29 \mathrm{a}$ & $0.31 \mathrm{a}$ & $0.37 b$ & $0.48 \mathrm{a}$ & $0.61 \mathrm{a}$ & $0.58 \mathrm{a}$ & $0.49 \mathrm{a}$ \\
\hline & Control & $0.27 \mathrm{~b}$ & $0.28 b$ & $0.32 \mathrm{c}$ & $0.41 \mathrm{c}$ & $0.48 c$ & $0.48 b$ & $0.44 \mathrm{~b}$ \\
\hline & & \multicolumn{7}{|c|}{ MDA (nmol g $\left.{ }^{-1} \mathrm{FW}\right)$} \\
\hline \multirow{2}{*}{ Sixing $F_{1}$} & Treatment & $2.45 \mathrm{c}$ & $2.91 \mathrm{~b}$ & $3.45 \mathrm{~b}$ & $4.05 \mathrm{c}$ & $4.61 \mathrm{c}$ & $4.69 \mathrm{c}$ & $4.35 \mathrm{c}$ \\
\hline & Control & $2.21 \mathrm{~d}$ & $2.45 \mathrm{c}$ & $2.88 \mathrm{c}$ & $3.27 \mathrm{~d}$ & $3.68 d$ & $3.71 \mathrm{~d}$ & $3.57 d$ \\
\hline \multirow{2}{*}{$\operatorname{Jin}_{12} F_{1}$} & Treatment & $2.87 \mathrm{a}$ & $3.35 \mathrm{a}$ & $3.68 \mathrm{a}$ & $5.07 \mathrm{a}$ & $5.31 \mathrm{a}$ & $6.66 \mathrm{a}$ & $5.98 \mathrm{a}$ \\
\hline & Control & $2.64 \mathrm{~b}$ & $2.85 \mathrm{~b}$ & $3.56 b$ & $4.68 \mathrm{~b}$ & $5.08 \mathrm{~b}$ & $5.19 b$ & $4.94 \mathrm{~b}$ \\
\hline
\end{tabular}

Data are means of 12 replicates. The different letters and treatments are detailed in the footnote of Table 2.

The POD activity in the Sixing $\mathrm{F}_{1}$ leaves was increased by $19.19 \%$ (Figure 3E) on the $9^{\text {th }}$ day and $9.21 \%$ in the $\operatorname{Jin}_{12} F_{1}$ leaves (Figure 3F) on the $11^{\text {th }}$ day after being inoculated with $P$. xanthii in comparison to the control seedlings inoculated with sterile water. It was significantly higher in the Sixing $F_{1}$ cultivar than in the $\operatorname{Jin}_{12} F_{1}$ cultivar, with a maximum activity of $10.33 \mathrm{U}$ $\mathrm{g}^{-1} \mathrm{~min}^{-1} \mathrm{FW}$ in the Sixing $\mathrm{F}_{1}$ leaves on the $9^{\text {th }}$ day and of $8.07 \mathrm{U} \mathrm{g}^{-1} \mathrm{~min}^{-1} \mathrm{FW}$ in the $\operatorname{Jin}_{12} \mathrm{~F}_{1}$ leaves on the $11^{\text {th }}$ day after inoculation.

Increased activities of APX were observed on the leaves of the Sixing $\mathrm{F}_{1}$ and $\operatorname{Jin}_{12} \mathrm{~F}_{1}$ cultivars by the inoculation with P. xanthii, and the induction reached its maximum on the $7^{\text {th }}$ and $9^{\text {th }}$ days and thereafter it declined. The APX activity was $5.60 \mathrm{U} \mathrm{g}^{-1} \mathrm{~min}^{-1}$ FW and $5.41 \mathrm{U} \mathrm{g}^{-1} \mathrm{~min}^{-1} \mathrm{FW}$ in the Sixing $\mathrm{F}_{1}$ leaves and 4.54 $\mathrm{U} \mathrm{g}^{-1} \mathrm{~min}^{-1} \mathrm{FW}$ and $4.57 \mathrm{U} \mathrm{g}^{-1} \mathrm{~min}^{-1} \mathrm{FW}$ in the $\operatorname{Jin}_{12} \mathrm{~F}_{1}$ leaves on the $7^{\text {th }}$ and $9^{\text {th }}$ days after inoculation, respectively. The APX activity was increased by 30.05 and $18.64 \%$ in the Sixing $F_{1}$ leaves (Figure 3G) and by 9.57 and $11.44 \%$ in the $\operatorname{Jin}_{12} \mathrm{~F}_{1}$ leaves (Figure $3 \mathbf{H}$ ) on the $7^{\text {th }}$ and $9^{\text {th }}$ days, respectively, after being inoculated with P. xanthii in comparison to the control seedlings inoculated with sterile water.

\section{Levels of Defense Genes Expression}

Compared with pumpkin leaves inoculated with sterile water, the expression levels of $P A L, P P O, S O D, P O D, C A T, A P X, P R 1$, $P R 2$, and ICS1 genes in the Sixing $\mathrm{F}_{1}$ and $\operatorname{Jin}_{12} \mathrm{~F}_{1}$ leaves were significantly upregulated after inoculation with $P$. xanthii at different time points (Figures 4-6). The expression levels of PAL, PPO, SOD, CAT, POD, APX, PR1, PR2, and ICS1 genes reached their maximum on the $7^{\text {th }}, 9^{\text {th }}$, and $11^{\text {th }}$ days after inoculation, and thereafter, they declined gradually in all the treatments. Also, there were significant differences in the expression levels of $P A L, P P O, S O D, P O D, C A T, A P X, P R 1, P R 2$, and ICS1 genes between the Sixing $F_{1}$ cultivar and the $\operatorname{Jin}_{12} F_{1}$ cultivar at different time points after inoculation. The expression levels of $P A L$ (Figure 4A), $P P O$ (Figure 4C), SOD (Figure 5A), $C A T$ (Figure 5C), $P O D$ (Figure 5E), $A P X$ (Figure 5G), $P R 1$ (Figure 6A), PR2 (Figure 6C), and ICS1 (Figure 6E) genes in the Sixing $F_{1}$ leaves were significantly higher than those in the Jin $_{12} \mathrm{~F}_{1}$ leaves (Figures 4B,D, 5B,D,F,H, 6B,D,F). The average expression levels of $P A L, P P O, S O D, C A T, P O D, A P X, P R 1, P R 2$, and ICS1 genes in the Sixing $\mathrm{F}_{1}$ leaves were 1. 16-, 1. 61-, 1. 46-, 1. 35-, 1. 19-, 1. 23-, 1. 38-, 1. 39-, and 1.33-fold higher than those in the $\operatorname{Jin}_{12} \mathrm{~F}_{1}$ leaves, respectively, at each sampling time from 1 to 13 days after inoculation.

\section{DISCUSSION}

Previous studies demonstrated that disease resistance screening was important to get tolerant germplasm for breeding new cultivars to control powdery mildew in field and greenhousegrown pumpkins (Luitel et al., 2016; Rabelo et al., 2017). Furthermore, the activation speeds and activity levels of defense enzymes vary in different plant genotypes or plant-pathogen interactions (Yan et al., 2009). Therefore, the changes in the levels of these enzymes could serve as valuable physiological indices for the selection of tolerant germplasms. In the present study, we evaluated the ability of two commercial pumpkin cultivars in resistance to $P$. xanthii infection. Our results demonstrate that the Sixing $F_{1}$ cultivar has a much higher ability in resistance to $P$. xanthii infection than the $\operatorname{Jin}_{12} \mathrm{~F}_{1}$ cultivar and can be considered as a tolerant variety. In addition, our results showed that the disease incidence and index were significantly higher than the Sixing $F_{1}$ cultivar at different time points after inoculation. The $\operatorname{Jin}_{12} \mathrm{~F}_{1}$ cultivar is a susceptible variety because of its high disease incidence and index.

Our comparative study of tolerant and susceptible cultivars provides a new insight for the mechanisms of different pumpkin cultivars in resistance to $P$. xanthii infection. The Sixing $\mathrm{F}_{1}$ cultivar had less ROS accumulation, lower rates of lipid peroxidation, a higher level of lignin and total phenolics contents, higher PAL, PPO activity, and genes expression, and a higher expression of SA signaling pathway marker genes than the $\operatorname{Jin}_{12}$ $\mathrm{F}_{1}$ cultivar. In addition, a positive relationship was discovered between the high $\mathrm{H}_{2} \mathrm{O}_{2}$ and MDA contents and the disease incidence and index. Thus, the possible mechanism for the stronger resistance of the Sixing $\mathrm{F}_{1}$ cultivar to $P$. xanthii infection may be through enhancing the activity and gene expression of the phenylpropanoids pathway and ROS scavenging and the 

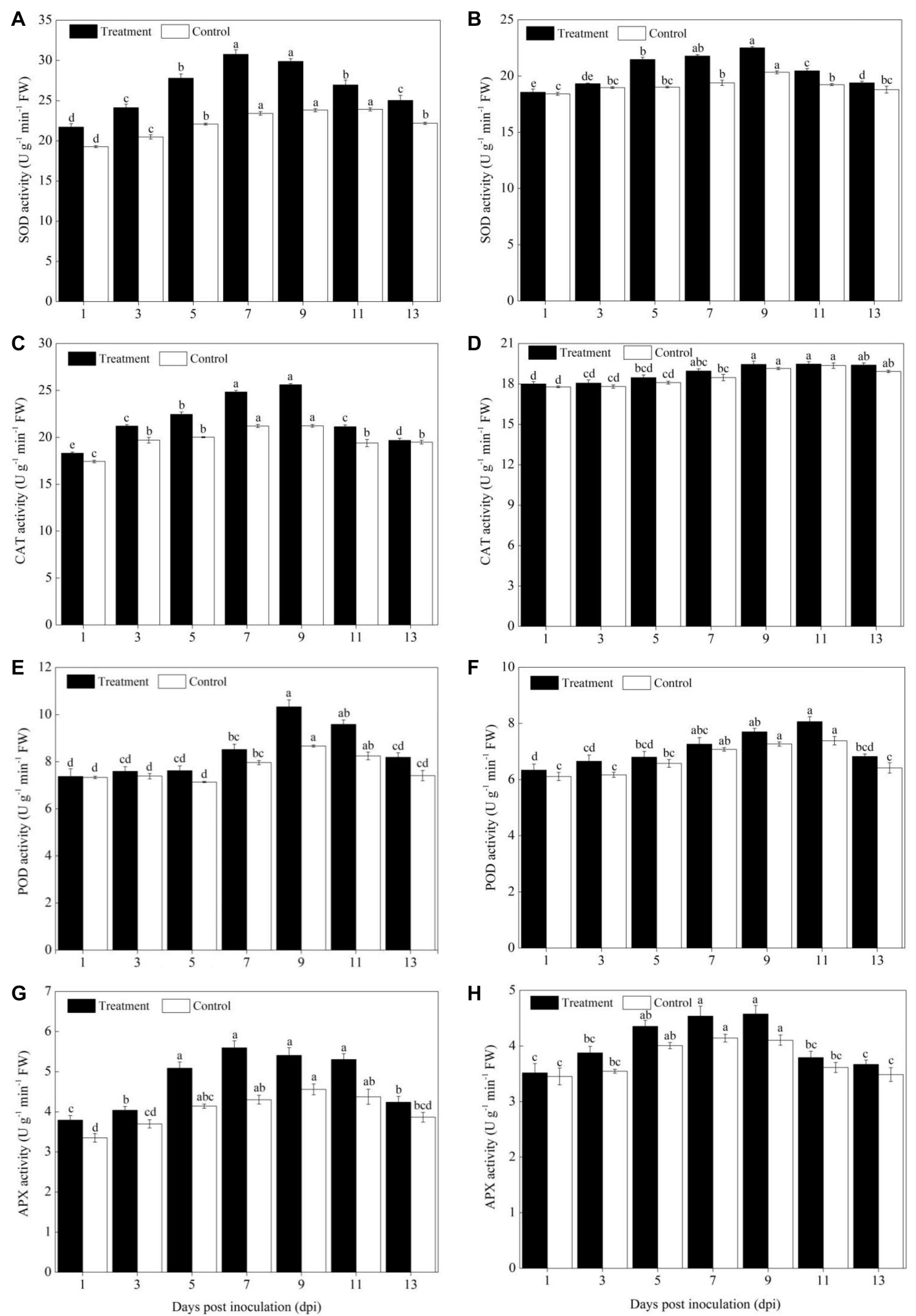

FIGURE 3 | Activities of ROS scavenging enzymes in the leaves of Sixing $F_{1}$ and $\operatorname{Jin}_{12} F_{1}$ at different time points after inoculation with Podosphaera xanthii. (A,C,E,G) The activity of SOD, CAT, POD, and APX in Sixing $F_{1}$, respectively; (B, D,F,H) the activity of SOD, CAT, POD, and APX in Jin 12 F 1 , respectively. The line bars, different letters, and the treatments are detailed in the footnote of Figure $\mathbf{2}$ and Table $\mathbf{2}$. 

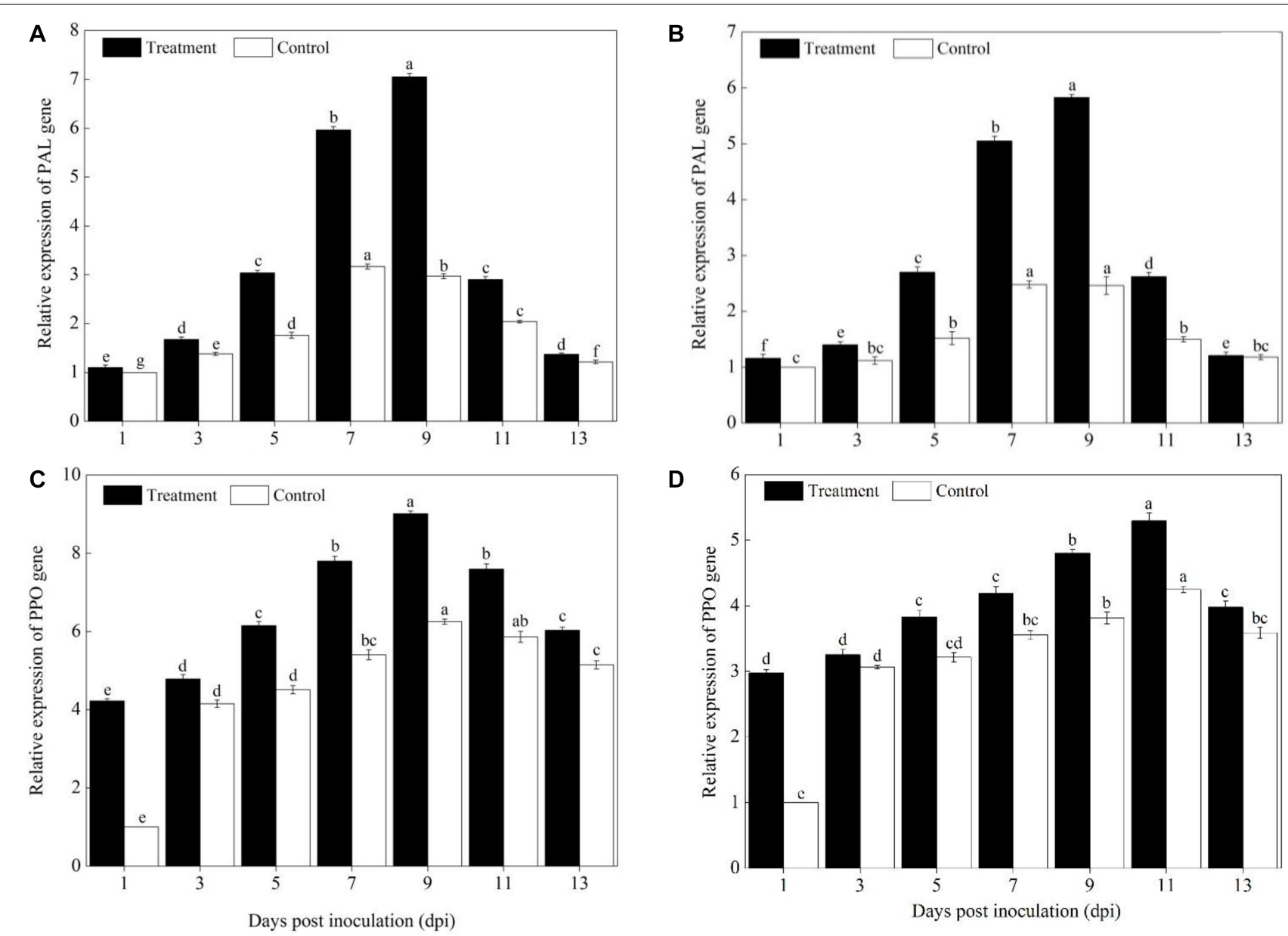

FIGURE 4 | Expression levels of $P A L$ and $P P O$ genes in the leaves of Sixing $\mathrm{F}_{1}$ and $\mathrm{Jin}_{12} \mathrm{~F}_{1}$ at different time points after being inoculated with $P$ odosphaera xanthii. $(\mathbf{A}, \mathbf{B})$ The expression levels of the PAL gene in Sixing $F_{1}$ and $\operatorname{Jin}_{12} F_{1}$, respectively; (C,D) the expression levels of the $P P O$ gene in Sixing $F_{1}$ and Jin 12 F

respectively. The line bars, different letters, and treatments are detailed in the footnote of Figure $\mathbf{2}$ and Table 2.

SA signaling pathway by increasing phenolic substances and lignin contents and reducing ROS accumulation. To the best of our knowledge, this is the first time that it was suggested that the pumpkin cultivars are resistant to $P$. xanthii infection through stimulating the phenylpropanoids and the SA pathway and antioxidative defense systems. These are also supported by previous studies.

Phenylpropanoid pathway defense enzymes (PAL, POX, and PPO) are known to be involved in plant disease resistance (Paparu et al., 2010; Babu et al., 2015; Jia et al., 2016) and closely related to plant resistance to $P$. xanthii of cucumber (Chen et al., 2014; Gao et al., 2019) and plant-induced systemic resistance (Mauch-mani and Slusarenko, 1996). Among all the phenylpropanoid pathway defense enzymes, PAL is the first enzyme that produces the precursors for lignin and phenolic secondary metabolites (Sticher et al., 1997). PPO is another key enzyme in the synthesis of phenolic compounds with antimicrobial activity (Babu et al., 2015; Jia et al., 2016; Niu et al., 2018). Muslim et al. (2019) revealed that the lignin deposition in cucumber plants can prevent the pathogen Colletotrichum orbiculare infection, and also the level of total phenolics was increased in cucumber seedlings after being inoculated with the P. xanthii (Chen et al., 2014).

The ROS-scavenging defense enzymes play an essential role in adjusting the extent of oxidative damage (Gao et al., 2020). Our present study found that the expression levels of ROS scavenging defense enzymes and genes ( $S O D, P O D, C A T$, and $A P X)$ were significantly increased in the tolerant cultivar of Sixing $\mathrm{F}_{1}$ after $P$. xanthii inoculation in agreement with the results of Wang et al. (2010) in the powdery mildew pathogen infested cucumber. $\mathrm{H}_{2} \mathrm{O}_{2}$ and MDA have been considered as the important types of ROS and key biochemical indicators of oxidative damage in plants against pathogen infection (Garcia-Limones et al., 2002; Mellersh et al., 2002; Gill and Tuteja, 2010; Mandal et al., 2011; Chavan et al., 2013). ElKomy (2014) demonstrated that the resistant cultivar faba bean (Vicia faba) showed less ROS accumulation, a lower rate of lipid peroxidation, and higher activity of the enzymatic ROS scavenging system compared with the susceptible cultivar during the interaction of Botrytis fabae. The ability of tomato 

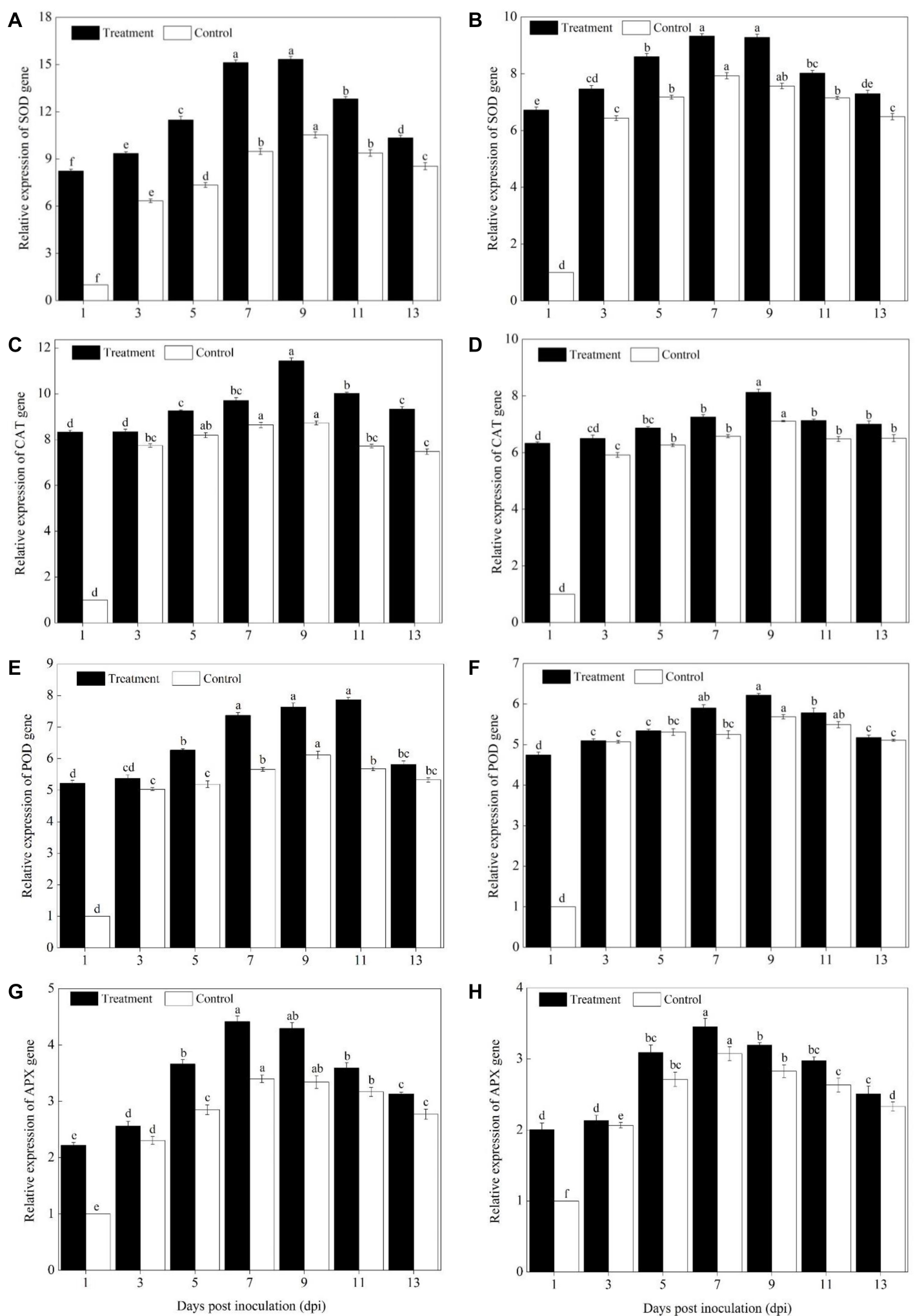

FIGURE 5 | Expression levels of ROS scavenging enzyme genes in the leaves of Sixing $\mathrm{F}_{1}$ and $\mathrm{Jin}_{12} \mathrm{~F}_{1}$ at different time points after being inoculated with Podosphaera xanthii. (A,C,E,G) The expression levels of SOD, CAT, POD, and APX genes in Sixing $\mathrm{F}_{1}$, respectively; (B,D,F,H) the expression levels of SOD, CAT, $P O D$, and $A P X$ genes in $\operatorname{Jin}_{12} \mathrm{~F}_{1}$, respectively. The line bars, different letters, and treatments are detailed in the footnote of Figure $\mathbf{2}$ and Table $\mathbf{2}$. 

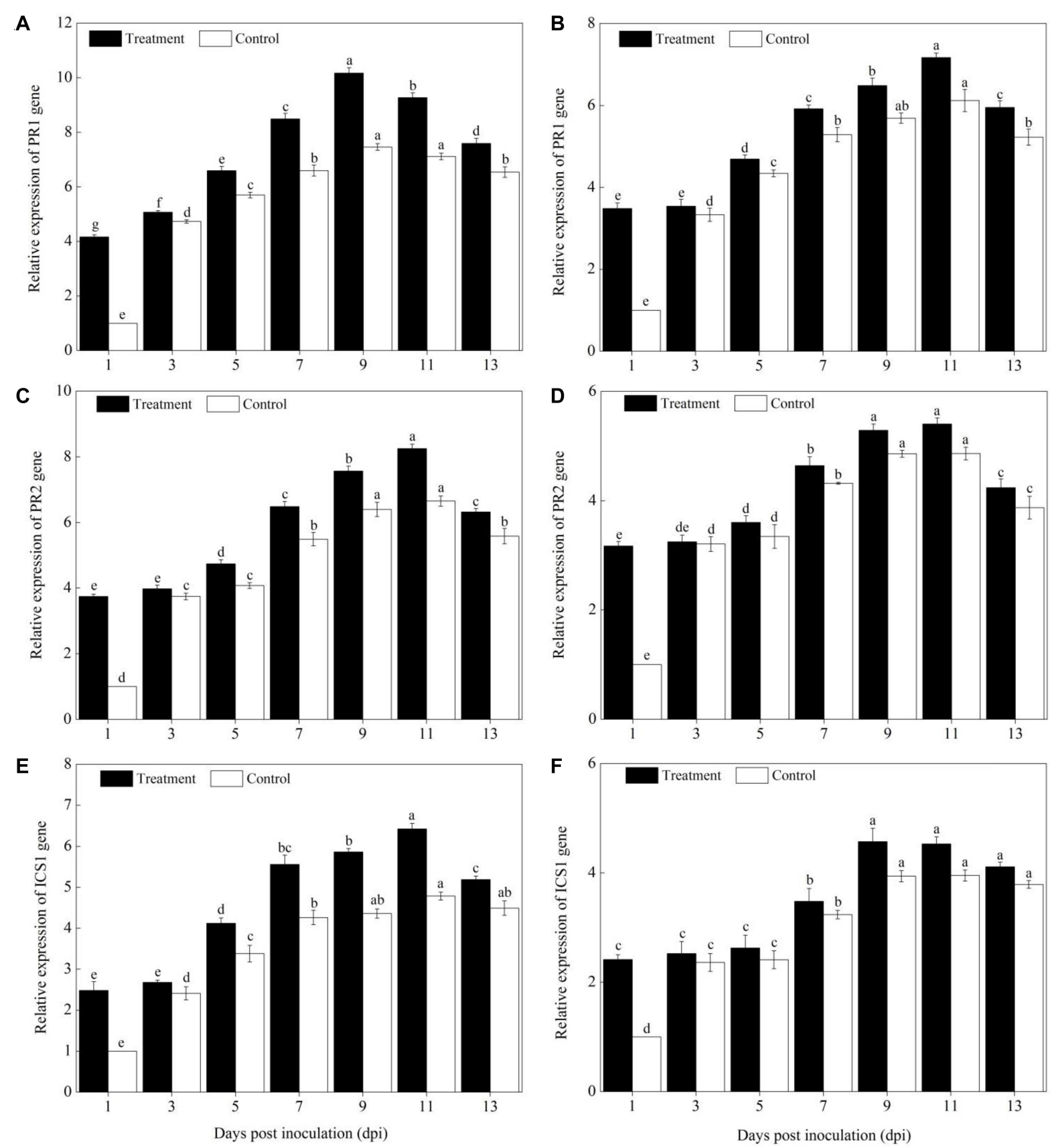

FIGURE 6 | Expression levels of SA signaling pathway marker genes in the leaves of Sixing $\mathrm{F}_{1}$ and $\mathrm{Jin}_{12} \mathrm{~F}_{1}$ at different time points after being inoculated with Podosphaera xanthii. (A,C,E) The expression levels of PR1, PR2, and ICS1 genes in Sixing F1, respectively; (B,D,F) the expression levels of PR1, PR2, and ICS1 genes in Jin $_{12} F_{1}$, respectively. The line bars, different letters, and treatments are detailed in the footnote of Figure 2 and Table 2.

(Lycopersicon esculentum L.) in resistance to Botrytis cinerea infection resulted from the early induction of $\mathrm{H}_{2} \mathrm{O}_{2}$ (Patykowski and Urbanek, 2003). Meanwhile, the excess $\mathrm{H}_{2} \mathrm{O}_{2}$ can lead to the peroxidation of unsaturated lipids of membranes in plants (Apel and Hirt, 2004) and the increased contents of MDA in both the resistant and susceptible cultivars of the faba bean during the interaction between $B$. fabae and faba bean (El-Komy, 2014).
Previous studies demonstrated that plant hormones of SA act as an important signal molecule in plant resistance to pathogen infection (Vlot et al., 2009). Meanwhile, similar studies revealed that the isochorismate synthase (ICS1/SID2) gene plays the main role in $\mathrm{SA}$ accumulation, and $P R$ gene acted as reliable markers of SA-mediated response or SAR as well as basal content maintenance under the normal condition (Hunt and Ryals, 1996; Garcion et al., 2008; Dempsey et al., 2011). 
Li et al. (2019) discovered that the basal defense and SA-signalingassociated pathways play an important role in contributing to the postpenetration defense against tobacco powdery mildew (Golovinomyces cichoracearum) in Arabidopsis by comparative transcriptome analysis. Wu et al. (2019) found that NPR1 and ICS1/SID2 genes can activate the SA pathway of Arabidopsis thaliana, and the increased expression of SA pathway marker genes PR2 and PR5 in A. thaliana plays a positive role in defense against (hemi)-biotrophs after the cold treatment.

\section{CONCLUSION}

Our study suggests that the Sixing $F_{1}$ cultivar can be considered as a tolerant cultivar, and the $\operatorname{Jin}_{12} \mathrm{~F}_{1}$ cultivar can be considered as a susceptible cultivar. One possible mechanism to activate the defense system and to prevent the pathogen infection of the pumpkin cultivars in resistance to $P$. xanthii infection is through enhancing the activity and gene expression of the enzymes involved in the phenylpropanoids pathway to promote the synthesis of phenolic substances and lignin and in ROS scavenging to reduce the ROS accumulation and to balance the oxidative damage, and in the SA signaling pathway to activate plant resistance to pathogen infection. However, more research is needed to determine other defense genes in pumpkins that encode the pathogenesis-related proteins and plant hormones in resistance to $P$. xanthii infection in the future.

\section{REFERENCES}

Abdel-Monaim, M., Abdel-Gaid, M., and Armanious, H. (2012). Effect of chemical inducers on root rot and wilt diseases, yield and quality of tomato. Int. J. Agric. Sci. 7, 211-220.

Apel, K., and Hirt, H. (2004). Reactive oxygen species: metabolism, oxidative stress, and signal transduction. Annu. Rev. Plant Biol. 55, 373-399. doi: 10.1146/ annurev.arplant.55.031903.141701

Babosha, A. V., Ryabchenko, A. S., Avetisyan, G. A., and Avetisyan, T. V. (2020). Visualization of the halo region in plant-powdery mildew interactions by cryoscanning electron microscopy. J. Plant Path. 102, 103-111. doi: 10.1007/ s42161-019-00387-3

Babu, A. N., Jogaiah, S., Ito, S., and Nagaraj, A. K. (2015). Improvement of growth, fruit weight and early blight disease protection of tomato plants by rhizosphere bacteria is correlated with their beneficial traits and induced biosynthesis of antioxidant peroxidase and polyphenol oxidase. Plant Sci. 231, 62-73. doi: 10.1016/j.plantsci.2014.11.006

Barickman, T. C., Horgan, T. E., and Wilson, J. C. (2017). Efficacy of fungicide applications and powdery mildew resistance in three pumpkin cultivars. Crop Prot. 101, 90-94. doi: 10.1016/j.cropro.2017.07.025

Bezold, T. N., Mathews, D., Loy, J. B., and Minocha, S. C. (2005). Molecular analysis of the hull-less seed trait in pumpkin: expression profiles of genes related to seed coat development. Seed Sci. Res. 15, 205-217. doi: 10.1079/SSR2005211

Cakmak, I., and Marschner, H. (1992). Magnesium deficiency and high light intensity enhance activities of superoxide dismutase, ascorbate peroxidase, and glutathione reductase in bean leaves. Plant Physiol. 98, 1222-1227. doi: 10.1104/ pp.98.4.1222

Chance, B., and Maehly, A. C. (1955). Assay of catalases and peroxidases. Meth. Enzymol. 2, 764-775. doi: 10.1016/S0076-6879(55)02300-8

Chang, S., Tan, C., Frankel, E. N., and Barrett, D. M. (2000). Low-density lipoprotein antioxidant activity of phenolic compounds and polyphenol oxidase

\section{DATA AVAILABILITY STATEMENT}

All datasets generated for this study are included in the article/supplementary material, further inquiries can be directed to the corresponding author/s.

\section{AUTHOR CONTRIBUTIONS}

SZ conceived the experiments with the help of BX. SZ collected and prepared the fungus and pumpkin seedling samples, performed Podosphaera xanthii infections, extracted the total RNAs, and wrote the manuscript. JL and SZ performed RT-qPCR and analyzed the data. SZ and JZ interpreted the results. JZ made critical revising, editing, and proofreading. SZ and BX revised and approved the final manuscript. All authors contributed to the article and approved the submitted version.

\section{FUNDING}

This work was supported by the Scientific Research Startup Funds for Openly-Recruited Doctors (Project 2017RCZX07); the Fuxi Outstanding Talent Cultivation Program, Gansu Agricultural University (Project Gaufx-03J03); the Special Funds for Discipline Construction (Project GAU-XKJS-2018156); and the National Natural Science Foundation of China (Project 31460526).

activity in selected clingstone peach cultivars. J. Agric. Food Chem. 48, 147-151. doi: 10.1021/jf9904564

Chavan, V., Bhargava, S., and Kamble, A. (2013). Temporal modulation of oxidant and antioxidative responses in Brassica carinata during B-aminobutyric acidinduced resistance against Alternaria brassicae. Physiol. Mol. Plant Pathol. 83, 35-39. doi: 10.1016/j.pmpp.2013.03.002

Chen, J., Fernandez, D., Wang, D. D., Chen, Y. J., and Dai, G. H. (2014). Biological control mechanisms of D-pinitol against powdery mildew in cucumber. Physiol. Mol. Plant 88, 52-60. doi: 10.1016/j.pmpp.2014.09.001

Chen, Q. M., Yu, G. C., Wang, X. Y., Meng, X. N., and Lv, C. M. (2020). Genetics and resistance mechanism of the cucumber (Cucumis sativus L.) against powdery mildew. J. Plant Growth Regul. 4, 1-7. doi: 10.1007/s00344020-10075-7

Cohen, Y., Baider, A., Petrov, L., Sheck, L., and Voloisky, V. (2000). Crossinfectivity of Sphaerotheca fuliginea to watermelon, melon and cucumber. Acta Hortic. 510, 85-88. doi: 10.17660/ActaHortic.2000.510.14

Dangl, J., and Jones, J. D. G. (2001). Plant pathogens and integrated defense responses to pathogens. Nature 411, 826-834. doi: 10.1038/35081161

Dempsey, D. A., Vlot, M. C. W., and Daniel, F. K. (2011). Salicylic acid biosynthesis and metabolism. Arabidopsis Book/American Soc. Plant Biol. 9:e0156. doi: 10.1199/tab.0156

Dik, A. J., Verhaar, M. A., and Bélanger, R. R. (1998). Comparison of three biological control agents against cucumber powdery mildew (Sphaerotheca fuliginea) in semi-commercial scale glasshouse trials. Eur. J. Plant Pathol. 104, 413-423. doi: 10.1023/A:1008025416672

Dong, X. (1998). SA. JA, ethylene, and disease resistance in plants. Curr. Opin. Plant Biol. 1, 316-323. doi: 10.1016/1369-5266(88)80053-0

Edgar, C. I., McGrath, K. C., Dombrecht, B., Manners, J. M., Maclean, D. C., Schenk, P. M., et al. (2006). Salicylic acid mediates resistance to the vascular wilt pathogen Fusarium oxysporum in the model host Arabidopsis thaliana. Australas. Plant Path. 35, 581-591. doi: 10.1071/AP06060 
El-Alfy, A. T., and Schlenk, D. (2002). Effect of 17-beta-estradiol and testosterone on the expression of flavin-containing monooxygenase and the toxicity of aldicarb to Japanese medaka. Oryzias latipes. Toxicol. Sci. 68, 381-388. doi: $10.1093 /$ toxsci/68.2.381

El-Komy, M. H. (2014). Comparative analysis of defense responses in chocolate spot-resistant and susceptible faba bean (Vicia faba) cultivars following infection by the necrotrophic fungus Botrytis fabae. Plant Pathol. J. 30, 355-366. doi: 10.5423/PPJ.OA.06.2014.0050

El-Naggar, M., El-Deeb, H., and Ragab, S. (2012). Applied approach for controlling powdery mildew disease of cucumber under plastic houses. Pak. J. Agric: Agric. Eng. Vet. Sci. (Pakistan) 28, 54-64.

Eskandari, S., Khoshgoftarmanesh, A. H., and Sharifnabi, B. (2018). The effect of foliar-applied manganese in mineral and complex forms with amino acids on certain defense mechanisms of cucumber (Cucumis sativus L.) against powdery mildew. J. Plant Growth Regul. 37, 481-490. doi: 10.1007/s00344-017-9747-x

Faostat (2010). Agricultural Structure (production, price, value). Rome: Food and Agriculture Organization.

Fu, Z. Q., Yan, S., Saleh, A., Wang, W., Ruble, J., Oka, N., et al. (2012). NPR3 and NPR4 are receptors for the immune signal salicylic acid in plants. Nature 486, 228-232. doi: 10.1038/nature11162

Gao, S. H., Xu, X. W., Zhang, R. Y., Qi, X. H., Xu, Q., and Chen, X. H. (2019). Cloning of CsPAL gene and its expression analysis in response to powdery mildew infection. Mol. Plant Breed. 17, 1757-1762.

Gao, Y. J., Fu, W. J., Liu, J., Chen, Y. J., and Dai, G. H. (2020). Morphological changes of Podosphaera xanthii and induced biochemical defenses of cucumber after treated by (+)-(S)-ar-turmerone. Physiol. Mol. Plant 112:101524. doi: 10.1016/j.pmpp.2020.101524

Garcia-Limones, C., Hervas, A., Navas-Cortes, J. A., Jimenez- Diaz, R. M., and Tena, M. M. (2002). Induction of an antioxidant enzyme system and other oxidative stress markers associated with compatible and incompatible interactions between chickpea (Cicer arietinum L.) and Fusarium oxysporum f. sp. ciceris. Physiol. Mol. Plant Pathol. 61, 325-337. doi: 10.1006/pmpp.2003. 0445

Garcion, C., Lohmann, A., Lamodiere, E., Catinot, J., Buchala, A., Doermann, P., et al. (2008). Characterization and biological function of the isochorismate synthase 2 gene of Arabidopsis. Plant Physiol. 147, 1279-1287. doi: 10.1104/pp. 108.119420

Giannopolitis, C. N., and Ries, S. K. (1977). Superoxide dismutases: I. occurrence in higher plants. Plant Physiol. 59, 309-314. doi: 10.1104/pp.59.2.309

Gill, S. S., and Tuteja, N. (2010). Reactive oxygen species and antioxidant machinery in abiotic stress tolerance in crop plants. Plant Physiol. Biochem. 48, 909-930. doi: 10.1016/j.plaphy.2010.08.016

Hafez, Y. M., El-Nagar, A. S., Elzaawely, A. A., Kamel, S., and Maswada, H. F. (2018). Biological control of Podosphaera xanthii the causal agent of squash powdery mildew disease by upregulation of defense-related enzymes. Egyptian J. Biol. Pest Cont. 28:57. doi: 10.1186/s41938-018-0058-8

Han, C., Li, J., Jin, P., Li, X., Wang, L., and Zheng, Y. (2017). The effect of temperature on phenolic content in wounded carrots. Food Chem. 215, 116123. doi: $10.1016 /$ j.foodchem.2016.07.172

Hodges, D. M., DeLong, J. M., Forney, C. F., and Prange, R. K. (1999). Improving the thiobarbituric acid-reactive-substances assay for estimating lipid peroxidation in plant tissues containing anthocyanin and other interfering compounds. Planta 207, 604-611. doi: 10.1007/s004250050524

Hou, L., Wang, L. N., Wu, X. L., Gao, W., Zhang, J. X., and Huang, C. Y. (2019). Expression patterns of two pal genes of Pleurotus ostreatus across developmental stages and under heat stress. BMC Microbiol. 19:231. doi: 10. 1186/s12866-019-1594-4

Hu, Z. H., Zhang, W., Shen, Y. B., Fu, H. J., Su, X. H., and Zhang, Z. Y. (2009). Activities of lipoxygenase and phenylalanine ammonia lyase in poplar leaves induced by insect herbivory and volatiles. J. For. Res. 20, 372-376. doi: 10.1007/ s11676-009-0063-6

Hunt, M. D., and Ryals, J. A. (1996). Systemic acquired resistance signal transduction. Crit. Rev. Plant Sci. 15, 583-606. doi: 10.1080/ 07352689609382371

Iiyama, K., and Wallis, A. F. A. (1990). Determination of lignin in herbaceous plants by an improved acetyl bromide procedure. J. Sci. Food Agric. 51, 145-161. doi: $10.1002 /$ jsfa. 2740510202
Irisarri, P., Zhebentyayeva, T., Errea, P., and Pina, A. (2016). Differential expression of phenylalanine ammonia lyase (PAL) genes implies distinct roles in development of graft incompatibility symptoms in Prunus. Sci. Hortic. 204, 16-24. doi: 10.1016/j.scienta.2016.03.025

Jia, H. F., Zhao, P. C., Wang, B. J., Tariq, P., Zhao, F. G., Zhao, M. Z., et al. (2016). Overexpression of polyphenol oxidase gene in strawberry fruit delays the fungus infection process. Plant Mol. Biol. Rep. 34, 592-606. doi: 10.1007/s11105-0150946-y

Kamalipourazad, M., Sharifi, M., Maivan, H. Z., Behmanesh, M., and Chashmi, N. A. (2016). Induction of aromatic amino acids and phenylpropanoid compounds in Scrophularia striata Boiss. cell culture in response to chitosaninduced oxidative stress. Plant Physiol. Biochem. 107, 374-384. doi: 10.1016/j. plaphy.2016.06.034

Kusch, S., and Panstruga, R. (2017). Mlo-based resistance: an apparently universal "weapon" to defeat powdery mildew disease. Mol. Plant-Microbe Interact. 30, 179-189. doi: 10.1094/MPMI-12-16-0255-CR

Li, R., Zhang, L. L., Yang, X. M., Cao, X. L., Wang, Y. G., Ma, X. F., et al. (2019). Transcriptome analysis reveals pathways facilitating the growth of tobacco powdery mildew in Arabidopsis. Phytopathol. Res. 1:7. doi: 10.1186/s42483019-0012-z

Liu, J. T., Wang, B., Li, Y. P., Huang, L. F., Zhang, Q. R., Zhu, H. S., et al. (2020). RNA sequencing analysis of low temperature and low light intensity responsive transcriptomes of zucchini (Cucurbita pepo L.). Sci. Hortic. 265:109263. doi: 10.1016/j.scienta.2020.109263

Liu, X. B., Zhang, J. H., and Cui, C. S. (2006). Identification of pathogen and evaluation the resistance to pumpkin powdery mildew in heilongjiang province. China Cucurb. Veget. 1, 10-13.

Livak, K. J., and Schmittgen, T. D. (2001). Analysis of relative gene expression data using real-time quantitative PCR and the $2-\Delta \Delta \mathrm{Ct}$ method. Methods $25,402-408$. doi: 10.1006/meth.2001.1262

Luan, Q., Chen, C., Liu, M., Li, Q., Wang, L., and Ren, Z. (2019). CsWRKY50 mediates defense responses to Pseudoperonospora cubensis infection in Cucumis sativus. Plant Sci. 279, 59-69. doi: 10.1016/j.plantsci.2018.11.002

Luitel, B. P., Kim, S. G., Sung, J. S., Hur, O. S., Mun, S. Y., Rhee, J. H., et al. (2016). Screening of pumpkin (Cucurbita spp.) germplasm for resistance to powdery mildew at various stages of seedlings growth. Res. Plant Dis. 22, 133-144. doi: 10.5423/RPD.2016.22.3.133

Mandal, S., Das, R. K., and Mishra, S. (2011). Differential occurrence of oxidative burst and antioxidative mechanism in compatible and incompatible interactions of Solanum lycopersicum and Ralstonia solanacearum. Plant Physiol. Biochem. 49, 117-123. doi: 10.1016/j.plaphy.2010.10.006

Mauch-mani, B., and Slusarenko, A. J. (1996). Production of salicylic acid precursors is a major function of phenylalanine ammonia-lyase in the resistance of Arabidopsis to Peronospora parasitica. Plant Cell 8, 203-212. doi: 10.2307/ 3870265

McGrath, M. T., and Thomas, C. E. (1996). "Powdery mildew," in Compendium of Cucurbit Diseases, eds T. Zitter, A. D. L. Hopins, and C. E. Thomas (St. Paul, MN: APS Press), 28-30.

Mellersh, D. G., Foulds, I. V., Higgins, V. J., and Heath, M. C. (2002). $\mathrm{H}_{2} \mathrm{O}_{2}$ plays different roles in determining penetration failure in three diverse plant-fungal interactions. Plant J. 29, 257-268. doi: 10.1046/j.0960-7412.2001.01215.x

Morishita, M., Sugiyama, K., Saito, T., and Sakata, Y. (2003). Powdery mildew resistance in cucumber. Japan Agr. Res. Q. 37, 7-14. doi: 10.6090/jarq.37.7

Muslim, A., Hyakumachi, M., Kageyama, K., and Suwandi, S. (2019). Induction of systemic resistance in cucumber by hypovirulent binucleate Rhizoctonia against anthracnose caused by Colletotrichum orbiculare. Trop. Life Sci. Res. 30, 109-122. doi: 10.21315/tlsr2019.30.1.7

Nakano, Y., and Asada, K. (1981). Hydrogen peroxide is scavenged by ascorbatespecific peroxidase in spinach chloroplasts. Plant and Cell Physiol. 22, 867-880.

Niu, J. H., Cao, Y., Lin, X. G., Leng, Q. Y., Chen, Y. M., and Yin, J. M. (2018). Field and laboratory screening of anthurium cultivars for resistance to foliar bacterial blight and the induced activities of defence-related enzymes. Folia Hort. 30, 129-137. doi: 10.2478/fhort-2018-0013

Paparu, P., Dubois, T., Coyne, D., and Viljoen, A. (2010). Effect of Fusarium oxysporum endophyte inoculation on the activities of phenylpropanoid pathway enzymes and Radopholus similis numbers in susceptible and tolerant 
East African Highland bananas. Nematology 12, 469-480. doi: 10.1163/ 138855409X12571623969646

Patra, H. K., Kar, M., and Mishra, D. (1978). Catalase activity in leaves and cotyledons during plant development and senescence. Biochem. Physiol. Pflanzen 172, 385-390. doi: 10.1016/S0015-3796(17)30412-2

Patykowski, J., and Urbanek, H. (2003). Activity of enzymes related to $\mathrm{H}_{2} \mathrm{O}_{2}$ generation and metabolism in leaf apoplastic fraction of tomato leaves infected with Botrytis cinerea. J. Phytopathol. 151, 153-161. doi: 10.1046/j.1439-0434. 2003.00697.x

Rabelo, H. O., Santos, L. S., Diniz, G. M. M., Marin, M. V., Braz, L. T., et al. (2017). Cucurbits powdery mildew race identity and reaction of melon genotypes. Pesqui. Agropecu. Trop. 47, 440-447. doi: 10.1590/198340632017v4749537

Ruiz, J. M., Garcia, P. C., Rivero, R. M., and Romero, L. (1999). Response of phenolic metabolism to the application of carbendazim plus boron in tobacco. Physiol. Plant 106, 151-157. doi: 10.1034/j.1399-3054.1999.106201.x

Shi, Z. Q., Wang, F., Zhou, W., Zhang, P., and Fan, Y. J. (2007). Application of osthol induces a resistance response against powdery mildew in pumpkin leaves. Int. J. Mol. Sci. 8, 1001-1012. doi: 10.3390/18091001

Shin, H. D. (2000). Erysiphaceae of Korea. Suwon: National Institute of Agricultural Science and Technology, 227-235.

Singleton, V. L., and Rossi, J. A. (1965). Colorimetry of total phenolics with phosphomolybdic phosphotungstic acid reagents. Am. J. Enol. Vitic. 16, 144-158.

Smith, P. G. (1948). Powdery mildew resistance in cucumber. Phytopathology 38, 1027-1028.

Sticher, L., Mauch-Mani, B., and Metraux, J. P. (1997). Systemic acquired resistance. Annu. Rev. Phytopathol. 35, 235-270. doi: 10.1146/annurev.phyto. 35.1.235

Tanaka, K., Fukuda, M., and Amaki, Y. (2017). Importance of prumycin produced by Bacillus amyloliquefaciens SD-32 in biocontrol against cucumber powdery mildew disease. Pest Manag. Sci. 73, 2419-2428. doi: 10.1002/ps.4630

Tian, X. Y., He, M. R., Wang, Z. L., Zhang, J. W., Song, Y. L., He, Z. L., et al. (2015). Application of nitric oxide and calcium nitrate enhances tolerance of wheat seedlings to salt stress. Plant Growth Regul. 77, 343-356. doi: 10.1007/ s10725-015-0069-3

Vlot, A. C., Dempsey, D. A., and Klessig, D. F. (2009). Salicylic acid, a multifaceted hormone to combat disease. Annu. Rev. Phytopathol. 47, 177-206. doi: 10.1146/ annurev.phyto.050908.135202

Vlot, A. C., Klessig, D. F., and Park, S. W. (2008). Systemic acquired resistance: the elusive signal(s). Curr. Opin. Plant Biol. 11, 436-442. doi: 10.1016/j.pbi.2008.05. 003

Vogt, T. (2010). Phenylpropanoid biosynthesis. Mol. Plant 3, 2-20. doi: 10.1093/ $\mathrm{mp} / \mathrm{ssp} 106$
Wang, H., Jiang, Y. P., Yu, H. J., Xia, X. J., Shi, K., Zhou, Y. H., et al. (2010). Light quality affects incidence of powdery mildew, expression of defence-related genes and associated metabolism in cucumber plants. Eur. J. Plant Pathol. 127, 125-135. doi: 10.1007/s10658-009-9577-1

Wang, X. H., Gong, M., Tang, L., Zheng, S., Lou, J. D., Ou, L., et al. (2013). Cloning, bioinformatics and the enzyme activity analyses of a phenylalanine ammonialyase gene involved in dragon's blood biosynthesis in Dracaena cambodiana. Mol. Biol. Rep. 40, 97-107. doi: 10.1007/s11033-012-2032-y

Willekens, H., Chamnongpol, S., Davey, M., Schraudner, M., Langebartels, C., VanMontagu, M., et al. (1997). Catalase is a sink for $\mathrm{H}_{2} \mathrm{O}_{2}$ and is indispensable for stress defence in C-3 plants. EMBO J. 16, 4806-4816. doi: 10.1093/emboj/ 16.16 .4806

Wu, Z. J., Han, S. M., Zhou, H. D., Tuang, Z. K., Wang, Y. Z., Jin, Y., et al. (2019). Cold stress activates disease resistance in Arabidopsis thaliana through a salicylic acid dependent pathway. Plant Cell Environ. 42, 2645-2663. doi: 10.1111/pce.13579

Yan, H. X., Xu, B. L., Liang, Q. L., Xue, Y. Y., Chen, R. X., and Liang, Z. F. (2009). Effects of chlorophyll content and stoma density on pumpkin resistance to powdery mildew. Plant Prot. 35, 79-81.

Yan, Y. (2018). Functional Analysis of Low Temperature Tolerance Conferred by the GPA1-Encoded G Protein Subunit in Cucumis Sativus. Ph.D. thesis, China Agricultural University: Beijing

Yao, W. S., Xu, T. T., Farooq, S. U., Jin, P., and Zheng, Y. H. (2018). Glycine betaine treatment alleviates chilling injury in zucchini fruit (Cucurbita pepo L.) by modulating antioxidant enzymes and membrane fatty acid metabolism. Postharvest Biol. Tech. 144, 20-28. doi: 10.1016/j.postharvbio.2018.05.007

Zhang, S. W., Gan, Y. T., and Xu, B. L. (2016). Application of plant-growthpromoting fungi Trichoderma longibrachiatum T6 enhances tolerance of wheat to salt stress through improvement of antioxidative defense system and gene expression. Front. Plant Sci. 7:1405. doi: 10.3389/fpls.2016.01405

Zhu, H. S., Kang, J., Liu, J. T., Chen, M. D., Li, Y. P., Wang, B., et al. (2018). Cloning and expression analysis of polyphenol oxidase PPO gene family from Luffa cylindrical. J. Nucl. Agr. Sci. 32, 1502-1512.

Conflict of Interest: The authors declare that the research was conducted in the absence of any commercial or financial relationships that could be construed as a potential conflict of interest.

Copyright $\odot 2021$ Zhang, Liu, Xu and Zhou. This is an open-access article distributed under the terms of the Creative Commons Attribution License (CC BY). The use, distribution or reproduction in other forums is permitted, provided the original author(s) and the copyright owner(s) are credited and that the original publication in this journal is cited, in accordance with accepted academic practice. No use, distribution or reproduction is permitted which does not comply with these terms. 